\title{
Hodgkin's Lymphoma: From Tumor Microenvironment to Immunotherapeutic Approach - Body's Own Power Protection Challenges
}

\author{
Marylène Lejeune ${ }^{1}$, Luis de la Cruz-Merino² and Tomás Álvaro ${ }^{3}$ \\ ${ }^{1}$ Molecular Biology and Research Section, \\ Hospital de Tortosa Verge de la Cinta, IISPV, URV, \\ ${ }^{2}$ Clinical Oncology Department, Hospital Universitario Virgen Macarena, Sevilla, \\ Member of the Grupo Oncológico para el Tratamiento de las Enfermedades Linfoides \\ (GOTEL), \\ ${ }^{3}$ Pathology Department, Hospital de Tortosa Verge de la Cinta, IISPV, URV, \\ Spain
}

\section{Introduction}

Hodgkin's lymphoma (HL) is a highly curable disease and the reported results in last years relative to patient's survival were continuously improved. Cure rates $>90 \%$ for early HL and $>70 \%$ for those with advanced HL are expected. Nevertheless, there are high-risk patients (about 35\%) refractory to initial treatment or relapse after achieving complete remission. The current approaches to identify these patients employ pathologic, clinical and classical biologic prognostic factors. The relative scarcity of markers that could reliably predict long-term survival generates excessive treatments with both radio- and chemotherapy for many patients. In this condition, the identification of innovative biologic markers that could help to design appropriately tailored treatment strategies for classic HL (cHL) patients at high risk of treatment failure and patients with low-risk disease remains a crucial challenge.

The presence of a characteristic inflammatory microenvironment in response to tumoral cells not only distinguishes HL from other lymphomas, but even more, this is the main characteristic that makes HL a separate entity itself allowing its diagnosis. However, the functional role of the microenvironment in the pathophysiology of HL remains a matter of debate. The ability of the immune system to act as a double-edge weapon, protective or stimulating, indicates that tumoral clearance requires the effective coordination of the different elements of the immune system in an appropriate balance in quantity and quality. Therefore, current cancer research in HL aims to develop methods to increase the effectiveness of host antitumoral immune response, or at least prevent that various cytokines and growth factors from different subpopulation of infiltrating reactive immune response do not contribute to real growth of the tumoral Hodgkin and Reed-Sternberg (H/RS) cells. 
Biological therapy (also called immunotherapy, biotherapy or biological response modifier therapy) is one of the most promising strategies. These therapies use the body's immune system, either directly or indirectly, to fight HL or to help lessen the side effects of some cancer treatments for HL. Current biological therapy treatments for HL may be used either alone or in conjunction with other modalities such surgery, radiation and chemotherapy.

This chapter summarizes the data on clinical, histological, pathological and biological factors in HL, with special emphasis on the improvement of prognosis and their impact on therapeutical strategies. The recent advances in our understanding of HL biology and immunology seem indicate that infiltrated immune cells in the tumoral microenvironment may play different, even opposite, functions according to the signals it senses. Strategies aimed at interfering with the crosstalk between H/RS cells and their cellular partners have been taken into account in the development of new immunotherapy's that target different cell components of HL microenvironment. The current standard approaches with the use of combined modality therapy and systemic chemotherapy as well as the promising role of future response-adapted strategies is reviewed.

\section{Histopathological diagnostic parameters}

As classified by the World Health Organization (WHO), HL exists in 5 types (Swerdlow et al., 2008b). Four of these-nodular sclerosis (NSHL), mixed cellularity (MCHL), lymphocyte depleted (LDHL), and lymphocyte rich (LRHL) - are referred to as cHL. The fifth type, nodular lymphocyte predominant Hodgkin disease (NLPHL), accounts for 4-5\% of all HL cases and is a distinct entity with unique clinical features and a different treatment paradigm. Regarding cHL, NSHL represents the most common histological type in European countries, accounting for $40-70 \%$ of cases whereas MCHL account for about $30 \%$.

Histologically, cHL is characterized by a minority of neoplastic cells (1-2\%) named H/RS cells embedded in a rich background composed of a variety of reactive, mixed inflammatory cells consisting of lymphocytes, plasma cells, neutrophils, eosinophils, and histiocytes (Figure 1A). Thus, the presence of an appropriate cellular background-along with the results of immunophenotyping - is basic for the diagnosis. Evidence has accumulated that $\mathrm{H} / \mathrm{RS}$ cells harbor clonally rearranged and somatically mutated immunoglobulin genes, indicating their derivation, in most cases, from germinal center (GC) B-cells (Kuppers, 2002; Kuppers et al., 2003; Staudt, 2000; Thomas et al., 2004). Some HL cases have been identified in which the H/RS is of T-cell origin but these are rare, accounting for 1-2\% of cHL. Under normal conditions, GC B-cells, that lack a functional high affinity antibody, undergo apoptosis in the germinal center. H/RS cells show a characteristically defective B-cell differentiation program, lose the capacity to express immunoglobulin and, therefore, should die. However, H/RS cells escape apoptosis and instead proliferate, giving rise to the tumor and the immune response that characterizes (Kuppers, 2002; Kuppers et al., 2003; Staudt, 2000; Thomas et al., 2004). Gray zones between cHL and some types of diffuse B-cell lymphoma, especially primary mediastinal large B-cell lymphoma have been appreciated during these last 20 years (Campo et al., 2011). Both share a close biologic relationship and similar profiling at the epigenetic level (Eberle et al., 2011).

Concerning the phenotypic findings, expression of the CD30 molecule by H/RS cells is seen in more than $98 \%$ of cHLs although the intensity of the immunostaining can vary from one case to another, and even within the same case. CD30 molecule appears also to be a possible target for specific antibodies conjugated with toxins and administered to patients with cHL 

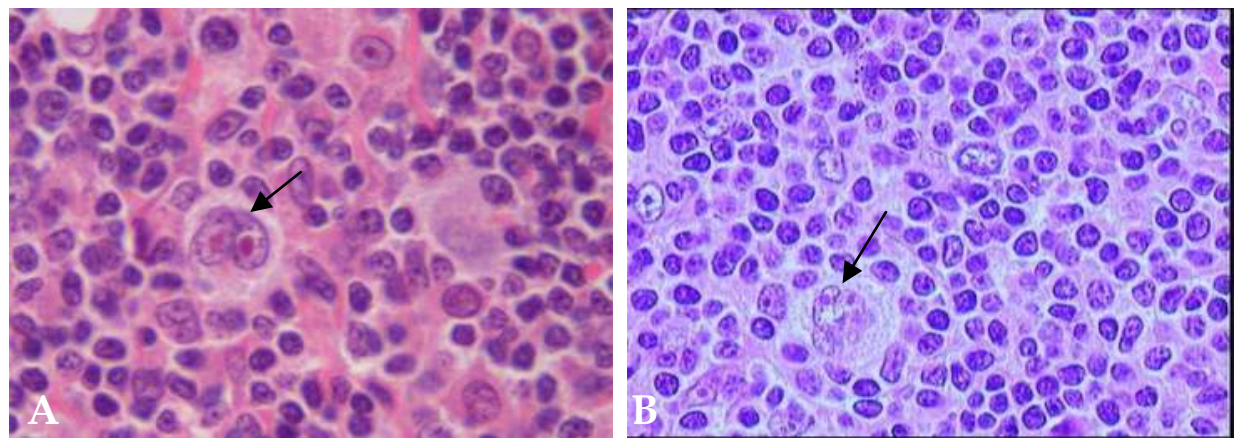

Fig. 1. Reed-Sternberg cell (A: black arrow) seen in a cellular background rich in lymphocytes of a classical Hodgkin lymphoma. Popcorn cell (B: black arrow) with typically lobated nuclei seen in a Nodular lymphocyte predominant Hodgkin lymphoma.

for therapeutic purposes. Preliminary studies have shown that these immunotoxins have remarkable cytotoxic activity (Falini et al., 1992; Foyil \& Bartlett, 2010; Tazzari et al., 1992). CD15, characteristic but not specific for H/RS, is detected in about $80 \%$ of cHL patients (Ascani et al., 1997; Foyil \& Bartlett, 2010; Pileri et al., 1991; Pileri et al., 1995). H/RS cells usually lack CD45 (Falini et al., 1990; Filippa et al., 1996; Korkolopoulou et al., 1994), whereas $\mathrm{B}$ and, to lesser extent, $\mathrm{T}$ cell markers are seen in a proportion of cases. In particular, CD20 is found in 30\%-40\% of cHL cases (usually EBV negative) (Filippa et al., 1996), and CD79a is found even less often (Tzankov et al., 2003a; Tzankov et al., 2003c; Watanabe et al., 2000). Positivity (usually weak) for one or more T cell marker is detected in a minority of cases in H/RS cells (Casey et al., 1989; Falini et al., 1987). Under these circumstances, single cell PCR studies have shown T-cell receptor (TCR) gene rearrangement in only three instances, with clonal Ig gene rearrangements occurring in most cHL cases with T-cell marker expression (Marafioti et al., 2000; Muschen et al., 2000). In contrast to that seen in NLPHL, the elements of cHL show variable expression of the BCL6 molecule (Stein et al., 2008b). Antibodies against the nuclear-associated antigens Ki-67 and proliferating cell nuclear antigen (PCNA) stain most H/RS cells, suggesting that a large number of neoplastic cells enter the cell cycle (Gerdes et al., 1987; Sabattini et al., 1993).

NLPHL differs greatly from the common type in terms of morphology, phenotype, genotype, and clinical behavior (Piccaluga et al., 2011). The only feature shared by NLPHL and cHL is the low number of neoplastic cells. The neoplastic population consists of large elements called lymphocytic/histiocytic or popcorn cells (Figure 1B) (Mason et al., 1994). However, these neoplastic cells have a characteristic profile, which differs greatly from that of cHL (Anagnostopoulos et al., 2000; Harris et al., 2000; Harris et al., 1994). In particular, they are $\mathrm{CD}_{4} 5^{+}, \mathrm{CD} 20^{+}, \mathrm{CD} 22^{+}, \mathrm{CD}_{9} \mathrm{a}^{+}, \mathrm{J} \mathrm{chain}^{+/-}, \mathrm{EMA}^{+/-}$, and CD15- ${ }^{-} \mathrm{CD} 30$ positivity is rare and, when detected, weak. Popcorn cells regularly express the transcription factor OCT2 and its coactivator BOB.1 (Stein et al., 2001). Although NLPHL is characterized by a more preserved B-cell phenotype compared to the classical variant, a certain degree of defectivity was also described since a downregulation of several markers associated with the B-cell lineage (CD19, CD37, CD79b, and LYN) and with the germinal center maturation stage (CD10, LCK, and PAG) have been observed (Tedoldi et al., 2007). In comparison to 
cHL, NLPHL has a higher age of onset (30-40 years), a higher incidence in males, a tendency for peripheral distribution, lack of B symptoms in the majority of cases, and mostly earlystage disease (Diehl et al., 1999; Nogova et al., 2008).

\section{Clinicobiological prognostic parameters}

The high curability rates of HL coupled with increasing awareness of late treatment related morbidity, especially in young population, has highlighted the importance of some clinicobiological risk factors that might guide the therapeutical strategies. Although these factors are probably the clinical translation of some alterations at the molecular level, to date there exist global consensus based upon these clinicobiological characteristics in order to decide the total amount of treatment to administer to every single patient, especially with respect to the type and number of cycles of chemotherapy, and thus to apply more intensive treatments to those cases with higher risk of relapse and, on the contrary, to avoid unnecessary treatment in patients with good prognosis.

\subsection{Staging and clinical risk categories}

Selection of treatments depends on initial risk stratification. In this sense, stage remains the most important factor in the initial approach for treatment of HL, being the Ann Arbor system with Cotswolds modifications the current staging system used for patients with HL (Table 1) (Diehl et al., 2004).

Stage I - Involvement of a single lymph node region (I) or of a single extralymphatic organ or site (Ie).

Stage II - Involvement of two or more lymph node regions on the same side of the diaphragm alone (II) or with involvement of limited, contiguous extralymphatic organ or tissue (IIe). The number of anatomic regions should be indicated by a subscript

Stage III - Involvement of lymph node regions or lymphoid structures on both sides of the diaphragm (III) which may include the spleen (IIIs) or limited, a contiguous extralymphatic organ or site (IIIe) or both (IIIes). This may be subdivided into stage III-1 or III-2: stage III-1 is used for patients with involvement of the spleen or splenic hilar, celiac or portal nodes; and stage III-2 is used for patients with involvement of the paraaortic, iliac, inguinal, or mesenteric nodes.

Stage IV - Diffuse or disseminated foci of involvement of one or more extralymphatic organs or tissues, with or without associated lymphatic involvement.

Table 1. Ann-Arbor/Costwolds staging system.

In clinical practice, HL is classified in early and advanced disease (Connors, 2005). Early disease includes stages I-II and it is generally divided into favorable and unfavorable categories based upon the presence or absence of certain clinical features, such as age, erythrocyte sedimentation rate (ESR), B symptoms, and large mediastinal adenopathy. Cooperative research groups have used diverse definitions of favorable and unfavorable prognosis disease (Table 2) (Specht \& Hasenclever, 1999).

However, probably the most commonly used definition of favorable/unfavorable disease is the one proposed by the European Organization for the Research and Treatment of Cancer 
(EORTC). Patients with one of the risk factors mentioned above are considered to have unfavorable prognosis early stage HL. This stratification is highly pertinent and useful since patients with favorable prognosis disease may have acceptable outcomes with less intensive therapy than that required for those with unfavorable prognosis early stage or advanced stage disease (Engert et al., 2010).

EORTC: age 50 or older; large mediastinal adenopathy; with an ESR of more than 50/h and B symptoms (or with an ESR of more than $30 \mathrm{~mm} / \mathrm{h}$ in those who have B symptoms); and disease with four or more regions of involvement

GHSG: Three or more sites of disease; extranodal extension; mediastinal mass measuring one-third the maximum thoracic diameter or greater; and ESR more than $50 \mathrm{~mm} / \mathrm{h}$ (more than $30 \mathrm{~mm} / \mathrm{h}$ if B symptoms present)

NCCN: large mediastinal adenopathy; bulky disease lager than $10 \mathrm{~cm}$; B symptoms; ESR more than $50 \mathrm{~mm} / \mathrm{h}$; and disease with four or more regions of involvement

NCI-C: age 40 or older; ESR more than $50 \mathrm{~mm} / \mathrm{h}$; and disease with four or more regions of involvement

Table 2. Definitions of unfavorable disease by different cooperative research groups.

Among patients with advanced stage HL (stage III/IV, and for some groups stage II plus bulky nodal disease), prognosis is largely determined by the International Prognostic Score (IPS) (Hasenclever \& Diehl, 1998). The IPS was created by the IPS Project on Advanced Hodgkin's Disease based upon the total number of seven potential unfavorable features at diagnosis: serum albumin less than $4 \mathrm{~g} / \mathrm{dL}$, hemoglobin less than $10.5 \mathrm{~g} / \mathrm{dL}$, male gender, age over 45 years, stage IV disease, white blood cell count $\geq 15,000 / \mathrm{microL}$, and lymphocyte count less than 600/microL and/or less than 8 percent of the white blood cell count.

In this system, one point is given for each of the above characteristics present in the patient, for a total score ranging from zero to seven, representing increasing degrees of risk. When applied to an initial group of 5141 patients with HL treated with combination chemotherapy ABVD-like with or without radiotherapy, event-free survival rates at five years correlated well with IPS (Table 3) (Hasenclever \& Diehl, 1998).

\begin{tabular}{|l|}
\hline No factors $-84 \%$ (7 percent of patients) \\
One factor $-77 \%$ (22 percent of patients) \\
Two factors $-67 \%$ ( 29 percent of patients) \\
Three factors $-60 \%$ (23 percent of patients) \\
Four factors $-51 \%$ (12 percent of patients) \\
Five or more factors $-42 \%$ (7 percent of patients) \\
\hline
\end{tabular}

Table 3. Event free survival correlated with IPS.

Consequently, different treatment policies are indicated upon the presence of these clinicobiological parameters, with application of more aggressive approaches when more risk factors are present.

\subsection{Positron Emission Tomography (PET) and correlation with clinical outcomes}

In the last years, F fluoro-2-deoxy-D-glucose positron emission tomography (FDG-PET) has been established as a potent tool that can provide early information about disease control in 
the course of antineoplastic therapy. Monitoring clinical evolution with PET is emerging as a new powerful predictor of outcome that can eventually diminish the amount of treatment to administer, sparing unnecessary cycles of chemotherapy or radiotherapy, or, on the contrary, making advisable the indication of more intensified treatments.

Some trials have revealed that interim PET scans after one to three cycles of chemotherapy may predict long term outcomes in HL (Hutchings et al., 2005). In a prospective trial including 260 patients with advanced HL treated with ABVD, PET scans were made per protocol after 2 cycles of treatment (Gallamini A et al, 2007). This study demonstrated that patients with an interim negative PET scan had excellent prognosis, with two year event free survival rates of $95 \%$, compared with $13 \%$ in those cases with PET positive. On multivariate analysis, interim PET status was the only significant prognostic factor, showing superiority over the classical IPS model (Gallamini et al., 2007).

After these findings, next question is how to incorporate the interim PET results in the global management of treatment of HL in order to tailor a risk-adapted treatment strategy to the individual patient. There are several prospective trials ongoing in the United States and in Europe in early and advanced disease, testing different therapeutic approaches depending on PET scan findings. Their results are eagerly awaited to definitely establish finer tune therapeutic strategies in this disease.

\section{Role of virus in HL}

A negative association has been observed between HL and repeated early common infections (Rudant et al., 2010). Viruses are etiologically associated with a significant number of human leukaemia/lymphomas. Recognition of virus involvement in these malignancies is important as prevention of infection can lead to a reduction in the number of individuals at risk of disease. Early epidemiologic data suggested that HL develops among persons with a delayed exposure to a ubiquitous infectious agent such as Epstein-Barr virus (EBV) or among persons with acquired less common new infections such as human deficiency virus (HIV). The role of mediators of immunity genes may be important in the lack of adequate immune control of infectious agents. Several cytokines and interleukins are produced by neoplastic cells in lymphomas.

EBV, a $\gamma$ herpesvirus with a worldwide distribution, is present in H/RS cells of $40 \%-60 \%$ of cHL lesions and contributes to their pathogenesis (Kapatai \& Murray, 2007; Khan, 2006). EBV positivity is higher with MCHL (60-70\%) than with NSHL (15-30\%). EBV+ H/RS cells express the latent membrane proteins 1, 2A y 2B (LMP1, LMP2A, LMP2B), the EBV nuclear antigens 1 (EBNA1), and the EBER RNAs, but consistently lack EBNA2 (latency II) (Jarrett, 2002, 2006). LMP1 is likely to contribute to survival and proliferation of $\mathrm{H} / \mathrm{RS}$ cells through activation of NF-kB and AP-1 (Kilger et al., 1998; Lam \& Sugden, 2003). The role of LMP2A is more difficult to predict. Although LMP2A can deliver a survival signal in B-cells, H/RS cells have down-regulated many B-cell specific molecules including intracellular components involved in this signaling pathway (Kilger et al., 1998; Schwering et al., 2003). LMP2A may indeed contribute to this 'loss of B-cell signature', since cDNA microarray analysis of LMP2A expressing B-cells reveals a similar pattern of downregulated genes (Portis et al., 2003). It is also possible that EBNA1 and the EBERs contribute to the rescue of H/RS cells from apoptosis (Kennedy et al., 2003; Young \& Rickinson, 2004). 
Immunologic reactions (cytotoxic responses) against EBV can occur in the peripheral blood of some cHL patients (Khan, 2006). It has been estimated that EBV-specific T-cells might constitute up to $5 \%$ of circulating CD8+ T-cells (Hislop et al., 2002; Rickinson \& Kieff, 2001). The intratumoral immunological alterations induced by $\mathrm{EBV}^{+} \mathrm{H} / \mathrm{RS}$ cells remain unclear. The abnormal network of cytokines/chemokines and/or their receptors in H/RS cells is involved in the attraction of many of the microenvironmental cells into the lymphoma background. There is increasing evidence suggesting a change in the balance between Th1 and Th2 cells in the pathogenesis of $\mathrm{HL}$ and that this change induces reactivation of latent viral infections, including EBV. For example, interleukin like IL-1 $\beta$ is produced by H/RS cells in culture (Hsu et al., 1989) and IL-3 have demonstrated to present significant biological activity as growth and antiapoptotic factor for H/RS cells (Aldinucci et al., 2005). Serum levels of the receptor antagonist IL-1 (IL-1r $\alpha$ ) are elevated in HL patients, patients with B symptoms have significantly lower levels of IL-1ra than those without symptoms (Gruss et al., 1992). IL-10 is a pleiotropic cytokine that protects hematopoietic cells from apoptosis induced by glucocorticoids and doxorubicin. H/RS cells express functional IL-10 receptors and elevated IL-10 levels may inhibit apoptosis of H/RS cells. Elevated serum IL-10 levels have been found in up to $50 \%$ of HL patients and have been associated with inferior failure free survival (FFS) and overall survival (OS) in patients treated with ABVD or BEACOPP chemotherapy (Rautert et al., 2008; Sarris et al., 1999; Vassilakopoulos et al., 2001; Viviani et al., 2000). Elevated serum IL-10 levels confer a poor survival and may add to the prognostic value of the IPS in prediction of outcomes in HL (Axdorph et al., 2000). CCL17/TARC is a chemokine secreted by H/RS cells and its chemotactic properties may explain the infiltration of reactive $\mathrm{T}$ lymphocytes in HL (Niens et al., 2008; Peh et al., 2001; van den Berg et al., 1999). Elevated CCL7/TARC levels have been seen in the majority of patients with HL (Niens et al., 2008). Persistent elevation of TARC after completion of treatment has been associated with poorer survival and could be important for treatment monitoring (Hnatkova et al., 2009; Weihrauch et al., 2005). EBVinfected H/RS cells were shown to stimulate also the stromal production of particular chemokines such as the interferon-inducible chemokine IP-10 (CXCL10) (Teichmann et al., 2005), Rantes/CCL5 (Aldinucci et al., 2008; Fischer et al., 2003), the ligand CCL28 (Hanamoto et al., 2004), CCL20 that is capable of attracting regulatory T cells (Baumforth et al., 2008) and the macrophage-derived chemoattractant (MDC)/CCL22 (Niens et al., 2008). It has been also suggested that immunologic reactions against EBV can occur in the peripheral blood of some cHL patients (Khan, 2006). However, no comprehensive characterization of intratumoral immunologic alterations induced by EBV+ H/RS cells has been described so far. EBV was shown to contribute to HL patients survival (Kapatai \& Murray, 2007). The observation of Th1/antiviral response in $\mathrm{EBV}^{+} \mathrm{CHL}$ tissues provides a basis for novel treatment strategies (Chetaille et al., 2009; Skinnider \& Mak, 2002).

Although HL is not considered an acquired immunodeficiency syndrome (AIDS)-defining neoplasm, HIV-infected patients treated with highly active antiretroviral therapy (HAART) present a higher incidence of HL compared with the population without HIV infection (Powles \& Bower, 2000; Powles et al., 2009). Almost 100\% of HIV-associated cases are EBVpositive and, in these patients, EBV is found more frequently in H/RS cells (Powles \& Bower, 2000). HIV-HL exhibits pathological features that are different from those of HL in "general population"(Carbone et al., 2009; Grogg et al., 2007) while is characterized by the predominance of unfavorable histological subtypes (MCHL and LDHL) (Carbone et al., 2009; Grogg et al., 2007; Tirelli et al., 1995). One of the peculiar clinical features of HIV-cHL 
is the widespread extent of the disease at presentation and the frequency of systemic Bsymptoms. At the time of diagnosis, $70-96 \%$ of the patients have B-symptoms, and $74-92 \%$ have advanced stages of disease with frequent involvement of extranodal sites, the most common being bone marrow (40-50\%), liver (15-40\%), and spleen (around 20\%) (Tirelli et al., 1995). The widespread use of HAART has resulted in substantial improvement in the survival of patients with HIV infection and lymphomas because of the reduction of the incidence of opportunistic infections and the opportunity to allow more aggressive chemotherapy. Moreover, the less-aggressive presentation of lymphoma in patients treated with HAART compared with untreated patients may also favorably change the outcome for HIV-infected patients with lymphomas (Vaccher et al., 2003). In fact, compared with patients who never received HAART, patients in HAART before the onset of cHL generally are older, have less B-symptoms, and a higher leukocyte and neutrophil counts and hemoglobin level (Chimienti et al., 2008).

\section{Antitumoral immunity}

Tumors are more than an accumulation of neoplastic cells; they might be more properly considered as a functional tissue immunologically mediated and formed by a complex tissue network in which neoangiogenesis, infiltrating immune competent cells, stromal cells, and a differentiated and specific extracellular matrix constitute the tumor microenvironment with the capacity of regulating cancer development (Alvaro et al., 2010; Tlsty \& Coussens, 2006). The interplay between the host immune system, malignant cells, and all other components of tumoral stroma determine proliferation, invasion, angiogenesis, and remodelling of extracellular matrix and metastasis.

The hypothesis of immunesurveillance postulates that one of the principal functions of the immune system would be recognizing neoplastic cells and eliminating them before they form tumors (Burns \& Leventhal, 2000). In these conditions, the absence of an effective immune system increases the risk of developing cancer. If the immune system is a complex system of different types of cells and molecules whose primary function is to act as an effective tumor suppressor, it is certain that the system may behave inefficiently, as indicated by the fact of tumors in immunocompetent individuals. Thus, in addition to the concept of immunosurveillance arises of immunostimulation (Ichim, 2005). Although various mechanisms could induce immunosuppression (virus, transplant ..), the increasing likelihood of cancer (Burnet, 1957) in immunologically intact individuals suggests that the immune response might not only be ineffective but may itself contribute to tumor progression (Prehn, 1972). That is, the immune system has the ability to act as a doubleedged sword, indicating that tumor elimination requires a good coordination of the various elements of the immune system.

The products of mutated or deregulated genes of tumoral cells contribute to the growth and invasion of tumoral cells, as well as to the expression of proteins with the ability to stimulate the immune response. The immunogenic capacity of the tumor can be evaluated by means of the study of the reactive infiltration, which is mainly composed by innate immune cells. The nature, function and specificity of the effector cells that drive the antitumoral immune response have been widely studied. Innate immunity is represented essentially by dendritic cells (DCs), macrophages, natural killer (NK), NK/T cells, neutrophils, cytokines and 
complement proteins, whereas adaptive immune cells are represented by B lymphocytes, $\mathrm{CD}^{+}$T-helper lymphocytes and $\mathrm{CD}^{+}$cytotoxic lymphocytes (CTL). The general mechanisms for tumor suppression have been principally attributed to $\mathrm{CD}^{+} \mathrm{T}$ helper lymphocytes. Cytokines and lymphokines from $\mathrm{CD} 4^{+} \mathrm{T}$ cells can also activate $\mathrm{CD} 8^{+} \mathrm{CTL}$, NK cells and macrophages, which have all been shown to be involved in tumor immunity (Adam et al., 2003; Gonthier et al., 2004; Ikeda et al., 2002; Peipp \& Valerius, 2002; Smyth et al., 2002). Immunoregulatory cytokines such as IL-10 and TGF- $\beta$ play an important role in immune tolerance, and it seems that suppressor effect of regulatory $\mathrm{T}$ cells $\left(\mathrm{CD} 4{ }^{+} \mathrm{CD} 25^{+}\right)$on the development of tumor associated antigen-reactive lymphocytes is independent of cytokines (Aldinucci et al., 2005). Contributing to the complexity of the interactions between the reactive background and malignant cells, immune cells present in the local infiltrate have proved capable of modulating apoptosis and of inducing proliferation of tumoral cells via death receptors, cytotoxic granule liberation, and withdrawal of growth factors or production of immunosuppressive cytokines (Atkinson \& Bleackley, 1995; Berke, 1995; de Visser \& Kast, 1999; Skinnider \& Mak, 2002). The efficacy of tumoral-immune cells interactions depends on several factors, such as the expression of MHC class I molecules and immunogenic epitopes in tumoral cells, the type of immune cell and the accessibility of tumor cells.

Tumor antigens recognized by $\mathrm{T}$ cells (generally $\mathrm{CD} 8+$ lymphocytes) represent the principal target of antitumoral immunity and are presented by MHC class I molecules; that is to say, that tumoral cells behave as antigen presenting cells (APC), presenting their own antigens to T cells. Naturally, professional APC can also present antigens to CD4 $4^{+}$lymphocytes through MHC class II molecules (Quezada et al., 2010). Dendritic cells (DC) and other APC are dispersed between tissues as sentinels or alarm systems ready to detect the presence of foreign antigens. While in the tumor microenvironment IL-12 production tends to be suppressed, resulting in a decrease in Th1 activity, DCs represent probably the most important regulators of naïve $\mathrm{T}$ cells, with a great capacity to produce and release IL-12. In their process of polarization, DCs are under the influence of inflammatory mediators such as prostaglandins produced by macrophages, fibroblasts, and tumor cells. A new route of junction between innate and adaptive immunity through the interaction between DC and NK cells has been suggested (Adam et al., 2005). Actually, at least four distinct CD4 T cells subsets have been described: Th1, Th2, Th17, and regulatory T cells, each one with a unique cytokine secretion pattern and function (Zhu \& Paul, 2008). Their primary roles is providing cytokines for the development of CTL, in addition to being able to secrete tumor necrosis factor (TNF) and interferon (IFN)-gamma, which can increase the expression of MHC class I by the tumor cell and therefore increase its sensitivity to CTL lysis. Among natural CTL, natural killer cells (NK cells) can be activated directly by contact with the tumor or as a result of the stimulus provided by cytokines. In addition, lymphokine-activated killer cells (LAK) are a group of NK cells derived from peripheral blood cells or tumor infiltrating lymphocytes (TIL) in patients with high concentrations of IL-2 and show a high capacity, nonspecific in this case, to lyse tumor cells. Others cellular mediators such as the macrophages are also capable of lysing tumor cells by releasing a large amount of lysosomal enzymes and reactive oxygen metabolites. Once activated they also produce cytokines such as TNF that exerts its cytotoxic activity triggering apoptosis in a similar way to that mediated by Fas. 


\section{Molecular markers}

In HL, a striking feature of both NLPHL and cHL entities is that the malignant cells account for only around 1\% of the tumor mass (Stein et al., 2008a). However, notable significant differences exist between these entities in terms of natural history, relation to EBV, cell morphology, phenotype, molecular characteristics, and clinical behavior (Farrell \& Jarrett, 2011; Maggioncalda et al., 2011).

There is compelling evidence that H/RS cells are clonal B cells that have lost their B cell phenotype. Effectively, H/RS cells, from nearly all cHL cases, and malignant popcorn cells from NLPHL have detectable rearrangements of Ig heavy and/or light chain genes, confirming a B cell origin (Kuppers et al., 1996; Kuppers et al., 1994) and, in any given case, the rearrangements are identical, proving the clonal nature of the disease (Kanzler et al., 1996; Kuppers et al., 1994; Marafioti et al., 2000). Furthermore, the Ig variable (IgV) gene regions show evidence of somatic hypermutation, revealing a GC or post-GC origin (Kuppers, 2002). It was also suggested that cHL and B cell non-Hodgkin lymphoma (BNHL) arisen from a common precursor (pre-GC or GC B cell) since both generally harbor identical $\mathrm{IgV}$ gene rearrangements but have distinct somatic Ig gene mutations (Brauninger et al., 2006). Intraclonal $\mathrm{IgV}$ gene diversity is observed in popcorn cells, indicating ongoing somatic hypermutation, whereas identical somatic hypermutations were observed in H/RS cells indicating a later stage of B cell differentiation (Kanzler et al., 1996; Kuppers et al., 1994; Marafioti et al., 2000). Around 25\% of cHL cases present non-functional Ig genes due to "crippling" mutations (Brauninger et al., 2006; Kanzler et al., 1996; Kuppers et al., 1994; Kuppers et al., 2001). H/RS cells harbor uncommonly rearranged T cell receptor genes $(<2 \%)$, suggesting a T cell origin in a small minority of cases (Muschen et al., 2001; Muschen et al., 2000; Seitz et al., 2000). At phenotypic level, markers of B lineage (CD20, CD19, CD79, surface Ig) and transcription factors (OCT2, BOB1 and PU1) are generally down-regulated in H/RS cells (Hertel et al., 2002; Schwering et al., 2003), and expression of the B cell-specific transcription factor PAX5 is usually retained (Foss et al., 1999). In contrast, popcorn cells express B cell markers including CD20, CD79, PAX5, OCT2 and BOB1. The global suppression of the $B$ cell signature results from transcriptional reprogramming (Kuppers et al., 2003; Mathas et al., 2006; Nie et al., 2003; Renne et al., 2006; Smith et al., 2005; Ushmorov et al., 2006; Ushmorov et al., 2004).

Mature B cells lacking B cell receptors would normally die by apoptosis, and therefore H/RS cells must have developed mechanisms to facilitate survival. The escape from apoptosis and transcriptional reprogramming of H/RS cells are interlinked and seem important to disease pathogenesis. EBV gene products appear to contribute to H/RS cell survival, proliferation and reprogramming through dysregulation of several signaling networks and transcription factors such as intrinsic overexpression of CD30 (Horie et al., 2002), deleterious mutations of the genes encoding IкB proteins ( $\mathrm{I} \kappa \mathrm{B} \alpha$ ) (Emmerich et al., 1999; Emmerich et al., 2003; Jungnickel et al., 2000; Lake et al., 2009; Wood et al., 1998) and amplification of the chromosomal region including the c-Rel gene (Barth et al., 2003; Joos et al., 2002; Martin-Subero et al., 2002). In cHL EBV-associated cases, the virus can contribute directly to activation of NF- $\mathrm{kB}$ though its protein latent membrane protein 1 (LMP-1), which mimics CD40 signaling. Mutations of genes encoding inhibitors and regulators of NF- $\mathrm{B}$ such as inactivating mutations of the TNF- $\alpha$ induced protein 3 (TNFAIP3) gene have been 
detected in a large proportion of EBV-negative cases (Kato et al., 2009; Schmitz et al., 2009). Others genomic lesions affecting different signaling pathways in H/RS cells (JAK-STAT, PI3K-Akt-mTOR, MAPK-MEK-ERK and AP1-JunFos) have also been demonstrated (Dutton et al., 2005; Emmerich et al., 1999; Joos et al., 2003; Juszczynski et al., 2007; Kube et al., 2001; Skinnider et al., 2002; Weniger et al., 2006; Zheng et al., 2003). In cHL and primary mediastinal B-cell lymphoma, genomic breaks of the major major histocompatibility complex (MHC) class II transactivator CIITA have been demonstrated to be highly recurrent (15\% and 38\% respectively) (Steidl et al., 2011b). The functional consequences of CIITA gen fusions is the downregulation of surface HLA class II expression and overexpression of ligands of the receptor molecule programmed cell death 1 (CD274/PDL1 and CD273/PDL2). These receptor-ligand interactions have been shown to impact anti-tumour immune responses in several cancers, whereas decreased MHC class II expression has been linked to reduced tumour cell immunogenicity.

Several of these recurring genetic lesions appear correlated with disease outcome (Slovak et al., 2011). Nonrandom DNA copy number alterations in cHL (H/RS cells CD $\left.30^{+}\right)$have been identified in the molecular karyotypes of cHL as comparing with the genomic profiles of GC B cells. Frequent gains $(>65 \%)$ were associated with growth and proliferation, NF-kB activation, cell-cycle control, apoptosis, and immune and lymphoid development. Frequent losses $(>40 \%)$ observed encompassed tumor suppressor genes, transcriptional repressors and SKP2 (Slovak et al., 2011).

Thus, multiple transcriptional and signaling pathways are disrupted in HL, and are thought to cooperate to increase H/RS cell proliferation, reduce apoptosis and promote a favorable cellular microenvironment through the release of multiple cytokines and chemokines. These findings may be useful prognostic markers in the counselling and management of patients and for the development of novel therapeutic approaches in primary refractory HL.

\section{Biological factors: Immune response in $\mathrm{HL}$}

The tumor microenvironment consists of a specific mixture of immune cells that express a distinctive profile for each tumor type, from which the efficacy of the immune response against the tumor is eventually derived (Alvaro et al., 2009). Exist increasing evidence of the importance of the microenvironment in the molecular pathogenesis of HL (Steidl et al., 2011a), and a promising therapeutic target has been raised focused on this approach. The presence of a characteristically rich inflammatory background particularly distinguishes HL from other lymphoproliferative syndromes. Differences in gene expression profiles of malignant cells in lymphoproliferative syndromes do not always determine the aggressiveness of the lymphoma, while recent contributions determine that HL represents the prototypical tumor in which the interplay between H/RS and the reactive microenvironment determines not only the histological morphology and classification but also the clinicopathological features and prognosis of these patients. Quantitative analysis of infiltrating immune cells reveals undisclosed relationships between the relative proportion of these cells and HL clinical outcome, illustrating how factors other than tumoral cellularity, or the immunophenotype and molecular anomalies present in the H/RS cells, can play a role in tumoral behaviour. 


\subsection{Patterns of immune response in $\mathrm{HL}$ and prognosis}

An abnormal pattern with overexpression of cytokines and their receptors is characteristic in H/RS cells. This pattern explains the abundant mixture of inflammatory cells, stromal changes and the predominance of Th2 cells between the various subpopulations of lymphoid cells in the tumoral microenvironment of HL (Swerdlow et al., 2008b). A predominance of $\mathrm{CD}^{+} \mathrm{T}$ lymphocytes in the background of tumoral cells in addition to a high number of cytotoxic cells (CD8, CD57, TIA-1) has been observed in the majority of HLtissues (Figure 2) (Alvaro-Naranjo et al., 2005; Oudejans et al., 1997; Poppema et al., 1998).

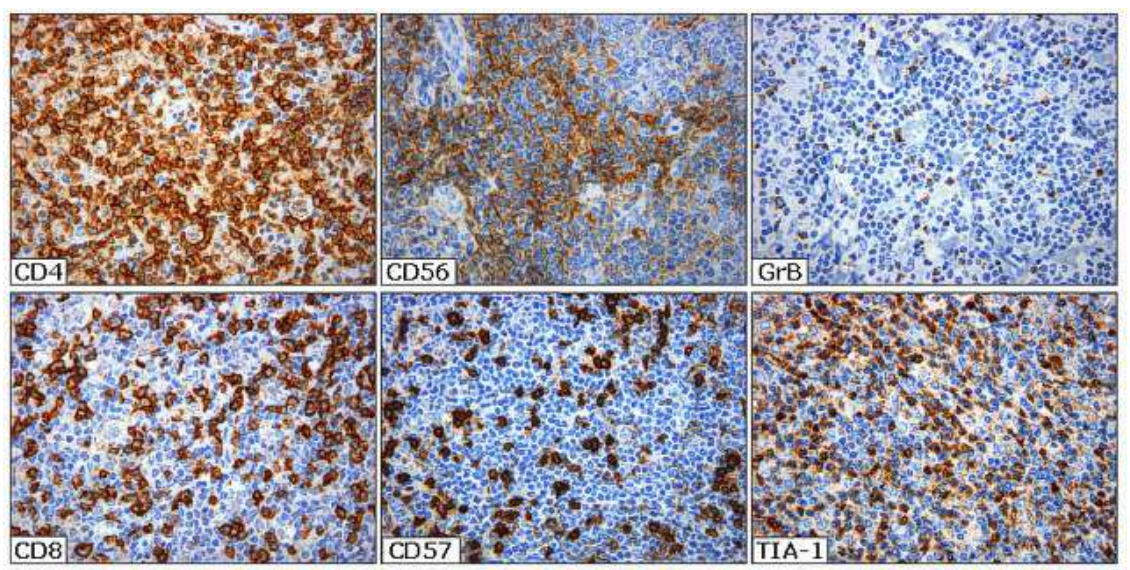

Fig. 2. Immunohistochemical staining of inflammatory background in HL: T lymphocytes (CD4 and CD8), NK cells (CD56 and CD57) and cytotoxic cells (GrB and TIA-1).

Regardless of the classic clinical and pathological features, a high proportion of infiltrating $\mathrm{CD}^{+}$and $\mathrm{CD}^{2} 7^{+}$cells as well as a low number of infiltrating CTL (evaluated by the presence of Granzyme B and TIA-1) appear to be associated with a favorable outcome for HL patients (without B symptoms and lower clinical stages) and better response to treatment (AlvaroNaranjo et al., 2005; Alvaro et al., 2005; Ansell et al., 2001). It is unclear to date whether the presence of $\mathrm{CD}^{+} \mathrm{T}$ cells correlates with the antitumor cytotoxic response. Nevertheless, it has been suspected that $\mathrm{CD}^{+} \mathrm{T}$ cells may be recruited in an antigen-non-specific mode in HL (Willenbrock et al., 2000).

Although the activation status of infiltrating cells have been demonstrated to be independent of the degree of malignancy in HL (Bosshart, 2002), others studies have shown that the presence of activated cytotoxic T cells (granzyme $\mathrm{B}^{+}$) is associated with unfavorable follow-up in these patients (Kanavaros et al., 1999; Oudejans et al., 1997; ten Berge et al., 2001). A higher level of not activated cytotoxic cells (TIA-1+) has been observed in advancedstage cHL without prognostic value (Camilleri-Broet et al., 2004). However, TIA-1+ CTL associated with the presence of regulatory $\mathrm{T}$ cells $\mathrm{FOXP3}^{+}$appears to play an important role in monitoring HL patients (Alvaro et al., 2005). Variations in the level ofcytotoxic TIA- $1^{+}$and regulatory $\mathrm{T}$ cells observed during the course of the disease could be implicated in the progression of HL (Alvaro et al., 2005). 

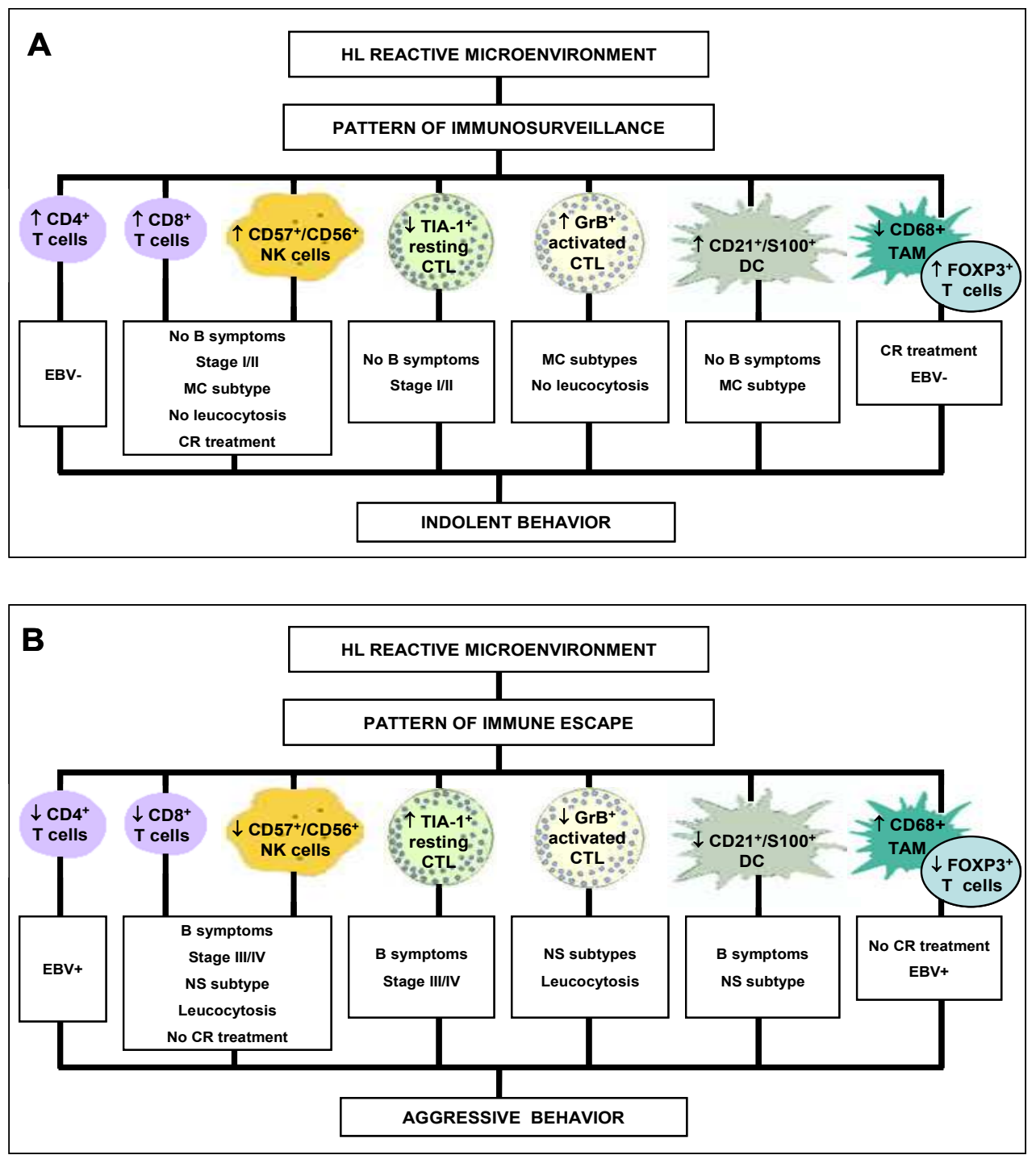

Fig. 3. Representation of the two immune patterns observed in HL significantly associated with their clinicopathological features. The immunesurveillance pattern (A) with a high proportion of infiltrating T lymphocytes, NK cells, DCs, activated CTL but low proportion of resting CTL and TAM is associated with a favorable outcome. The immune escape pattern (B) with a high proportion of infiltrating resting CTL and TAM, but low proportion of T lymphocytes, NK cells, DCs and activated CTL is associated with an unfavorable outcome. MC, mixed celularity; NS, nodular sclerosis; CR, complete response.

Association of tumor-associated macrophages (TAM) $\mathrm{CD}^{+} 8^{+}$with adverse clinical outcomes has been confirmed in several studies in hematologic and solid tumors (Pages et al., 2010). 
Recently, a gene expression profile analysis performed on 130 biopsy samples from patients with HL identified a signature of TAM and monocytes that was predictive of treatment failure (Steidl et al., 2010). In this study the sensitivity and specificity of this GEP signature for outcome in this cohort was greater than that of the International Prognostic Score (IPS). After these findings, biopsy samples from an independent cohort of 166 patients were evaluated with immunohistochemistry for the presence of CD68 expressing macrophages using a score from 1 to 3, from lower to higher infiltration (Steidl et al., 2010). When compared with those with low CD68 expression, patients with tumors that demonstrated an increased number of CD68 expressing macrophages had shorter median progression-free survival (PFS), lower rate of 10-year disease-specific survival (60 versus 89\%), and higher failure rate of secondary treatment with curative intent (63 versus $13 \%$ ). It has been also recently demonstrated that high level of CD68 correlated with poorer survival, event-free survival (EFS) and with the presence of EBV in the tumor cell population (Kamper et al., 2011). These results suggest a new pathological prognostic factor to be considered, however it is unclear at this time how CD68 status should affect patient management.

A plausible explanation for the extensive inflammatory infiltrate present in HL secretion could be a variety of cytokines produced by both tumor cells and surrounding stromal tissue. CD4 ${ }^{+}$ T cells produce Th2 cytokines that could contribute to local suppression of the cellular immune response mediated by Th1. However, the categorization of $\mathrm{CD}^{+} \mathrm{T}$ cells in Th1 and/or Th2 is an oversimplification (Marshall et al., 2004) as regulatory T cells with $\mathrm{CD} 4{ }^{+} \mathrm{CD} 25^{+}$phenotype not only play a regulatory role of autoimmunity, but also have suppressive effects on the development of antigen-reactive lymphocytes associated with the tumor (Wei et al., 2004). The H/RS cells secrete high amounts of chemokine, thymus and activation-regulated chemokine (TARC) and macrophages-derived chemokine (MDC) in particular, which attract lymphocytes expressing CCR4 receptor, such as Th2 (Skinnider \& Mak, 2002). These cytokines may contribute to the pathogenesis of the disease initiated and sustained the presence of the reactive infiltrate. Alternatively, immune cells can produce cytokines responsible for proliferation and survival of tumor, producing a positive feedback between the tumoral cells and immune system. The composition of the infiltrate may also differ depending on the state of immunosuppression of HL patients. Moreover, HIV infection affects, for direct or indirect mechanisms, both reactive changes as neoplastic lymphoid tissue. Recently we have seen a significant loss of intratumoral $\mathrm{T}$ cells $\mathrm{CD}^{+}(\mathrm{CD} 4 / \mathrm{CD} 8$ ratio reversal) and a decrease in intratumoral activated CTL in patients with HIV-infected HL (Bosch Princep et al., 2005). A low proportion of $\mathrm{CD}^{+}$cells appears also to be significantly related to EBV status, probably due to the relation with the local tumor-associated suppression of EBV-specific T-cell responses observed in $\mathrm{EBV}^{+} \mathrm{HL}$ cases (Frisan et al., 1995).

\subsection{Immune response regulation in $\mathrm{HL}$}

Tumors employ a plethora of immunosuppressive mechanisms, which may act in concert to counteract effective immune responses. Different mechanisms have been suggested to account for the CTL-mediated apoptosis resistance of H/RS cells, such as the downregulation of MHC class I molecules of the H/RS cells, prevention of recognition of tumor-associated antigens by CTLs (Poppema \& Visser, 1994), or the local secretion of both IL-10 and transforming growth factor-b by H/RS cells (Newcom et al., 1988; Ohshima et al., 1995), which are able to inhibit CTL function. In this respect, it appears that the blockage of 
the Granzyme B pathway of apoptosis through the overexpression of serine protease inhibitor PI-9/SPI-6 is an important additional mechanism for immune escape by tumors (Medema et al., 2001). The expression of PI9 tends to be associated with a high percentage of activated CTLs, especially in HL (Bladergroen et al., 2002), suggesting that PI9 may play a role in protecting against Granzyme B-induced apoptosis, and partially explaining why tumors expressing high levels of PI9 have a particularly poor clinical outcome, irrespective of the number of Granzyme $\mathrm{B}^{+}$cells in the inflammatory infiltrate.

Different subsets of immune cells contribute also to this immunosuppressive network, including $\mathrm{CD}^{+} \mathrm{CD} 25^{+}$regulatory $\mathrm{T}$ cells. In $\mathrm{HL}$, it has been initially proposed that $\mathrm{CD} 4{ }^{+} \mathrm{T}$ cells produce cytokines of Th2 type that could contribute to local suppression of the cellular immune response mediated by Th1 cells (Bladergroen et al., 2002; Poppema et al., 1999). However, the categorization of $\mathrm{CD}^{+} \mathrm{T}$ cells in Th1 and/or Th2 constitutes an oversimplification and it has been shown that regulatory $\mathrm{T}$ cells with $\mathrm{CD} 4{ }^{+} \mathrm{CD} 25^{+}$phenotype not only play a role in controlling autoimmunity, but also have suppressive effects on lymphocyte development tumor associated antigen reagents (Curiel et al., 2004; Fontenot et al., 2003; Suri-Payer et al., 1998). Functional and molecular characterization of these cells has been facilitated by the identification of markers such as FOXP3 and others (Shimizu et al., 2002; Sutmuller et al., 2001; Takahashi et al., 2000). FOXP3 encodes a transcription factor known as Scurfina, specifically expressed by T cells CD4 ${ }^{+} \mathrm{CD} 25^{+}($Karube et al., 2004), that acts converting naïve regulatory T cells CD4+CD25- phenotype to CD25+ (Hori et al., 2003). More recently, it was suggested that regulatory $\mathrm{T}$ cells and $\mathrm{PD} 1^{+} \mathrm{T}$ cells interact with $\mathrm{H} / \mathrm{RS}$ cells (Alvaro et al., 2005; Teichmann et al., 2005; Yamamoto et al., 2008), which produce the T regulatory attractant galectin-1 and the PD-1 ligand, PDL-1 (Yamamoto et al., 2008). On the other hand, the observation of numerous CXCR3+ lymphocytes in some HL tumors has raised the possibility of an occasional Th1-predominant immune response (Alvaro-Naranjo et al., 2005).

The regulatory $\mathrm{T}$ cells can inhibit the production of both IL-2 to regulate the high expression of IL-2Ra (CD25), ie, delay or block the activation of CD8 ${ }^{+}$cells and natural killer (NK) cells against tumor antigens (Azuma et al., 2003; Wolf et al., 2003). The immunosuppressive properties of regulatory $\mathrm{T}$ cells appear to be particularly important because of its large effect on cellular cytotoxicity represented by CTLs and NK cells. The presence of low numbers of FOXP3 ${ }^{+}$cells and a consequent high rate of TIA- $1^{+}$cells in the infiltrate represents an independent prognostic factor negatively affecting the survival of the disease. Furthermore, when the disease relapses and progresses, larger number of TIA-1+ cells and lower proportion of $\mathrm{FOXP}^{+}$on the reactive background of the tumor are also prone to be seen (Alvaro et al., 2005).

\section{Apoptotic and cell cycle pathways in $\mathrm{HL}$}

The aberrant expression of proteins involved in regulation and execution of apoptosis and cell cycle of lymphocytes has been demonstrated in several types of lymphoma and the importance of the level of apoptosis and proliferation in clinically aggressive lymphoproliferative syndromes (Bai et al., 2005; Bai et al., 2003; Garcia et al., 2003; SanchezBeato et al., 2003). These anomalies are probably not sufficient to explain the development of lymphomas, even if the effectiveness of therapy is presumed to be mediated by activation of apoptosis (Messineo et al., 1998). In HL, different studies have described alterations in genes 
controlling apoptosis and proliferation of H/RS cells and biological factors such as EBV detection, which influence the clinical aggressiveness of the disease (Bargou et al., 1997; Garcia et al., 1999; Hinz et al., 2002; Hinz et al., 2001; Izban et al., 2001; Kupper et al., 2001; Leoncini et al., 1997; Mathas et al., 2002; Montesinos-Rongen et al., 1999; Morente et al., 1997; Sanchez-Beato et al., 1996). These studies have demonstrated alterations of the p53, Rb and p27 tumor suppressor pathways (Bai et al., 2005; Garcia et al., 1999; Guenova et al., 1999; Hinz et al., 2001; Lauritzen et al., 1999; Montesinos-Rongen et al., 1999; Morente et al., 1997; Sanchez-Beato et al., 1996; Sanchez-Beato et al., 2003; Tzardi et al., 1996), overexpression of cyclins involved in the G1/S and G2/M transition such as cyclins E, D2, D3, A and B1 (Garcia et al., 2003; Kolar et al., 2000; Leoncini et al., 1997; Ohshima et al., 1999; Teramoto et al., 1999; Tzankov et al., 2003b), overexpression of cyclin-dependent kinases such as CDK1, 2 and 6 (Garcia et al., 2003) and overexpression of the anti-apoptotic proteins c-FLIP, bcl-xl, cIAP2 and surviving (Brink et al., 1998; Garcia et al., 2003; Kanavaros et al., 2000; Kuppers, 2002; Kuppers et al., 2003; Staudt, 2000; Thomas et al., 2004).

These findings raised the questions of how H/RS cells escape apoptosis, acquire selfsufficiency in growth signals and proliferate (Kuppers, 2002; Kuppers et al., 2003; Staudt, 2000; Thomas et al., 2004). The physiologic relevance of the deregulation of the cell cycle and apoptosis regulators in cHL could be related to the different probabilities of survival of HL patients. Many studies have analyzed the clinical relevance of the expression of cell cycle and apoptosis regulators in cHL using IHC or gene expression profiling (Brink et al., 1998; Devilard et al., 2002; Garcia et al., 2003; Montalban et al., 2000; Morente et al., 1997; Smolewski et al., 2000). Shorter survival was significantly associated with high proliferation index (Ki67), high expression of bcl2, bcl-xl, bax and p53, low expression of $\mathrm{Rb}$ and caspase 3 and high apoptotic index (Montalban et al., 2004; Rassidakis et al., 2002a; Rassidakis et al., 2002b; Sup et al., 2005; Abele et al., 1997; Brink et al., 1998; Garcia et al., 2003; Montalban et al., 2004; Morente et al., 1997; Smolewski et al., 2000). Evidence has accumulated that the constitutive activation of the NF- $\mathrm{kB}$ pathway in $\mathrm{H} / \mathrm{RS}$ cells is of particular importance for explaining the apoptosis deregulation in $\mathrm{cHL}$ by up-regulating an anti-apoptotic gene expression program (Bai et al., 2005; Hinz et al., 2002; Hinz et al., 2001; Mathas et al., 2002). By gene expression profiling, the good outcome cHL were characterized by up-regulation of genes involved in apoptosis induction (APAF, bax, bid, caspase 8, p53, TRAIL) and cell signaling, including cytokines and transduction molecules (IL-10, IL-18, STAT3), while the bad outcome cHL were characterized by upregulation of genes involved in cell proliferation (Ki67) and by down-regulation of tumor suppressor genes PTEN (Phospatase and Tensin homolog deleted on chromosome 10) and DCC (Deleted in Colorectal Cancer) (Devilard et al., 2002).

Within the complexity of the interactions between the reactive substance and tumor cells, immune cells present in the infiltrate have been shown to modulate the apoptosis and proliferation of tumor cells via apoptotic receptors, cytotoxic granule release, growth factors or immunosuppressive cytokines (Atkinson \& Bleackley, 1995; Berke, 1995; de Visser \& Kast, 1999; Famularo et al., 1994; Hahne et al., 1996). IHC study has demonstrated that the antiapoptotic profile observed in H/RS cells is associated with a general increase in CD4 ${ }^{+} \mathrm{T}$ cells infiltrating (related to Bcl-XL and Mcl-1) and an overall decline CD8 ${ }^{+} \mathrm{T}$ lymphocytes infiltrating, NK cells and dendritic cells (related to Bcl-XL and Bax) (Alvaro et al., 2008). Alterations observed in the G1-S checkpoint of H/RS cell cycle, in the principal tumor suppressor pathways Rb-p16INK4a and p27KIP1, and the high rate of proliferation (MIB1, BCL6) are also strongly associated with higher infiltration of the overall immune response 
against the tumor (Alvaro et al., 2008). These results point to the regulation of proteins involved in apoptosis and proliferation of tumor cells by direct interactions between these cells and the surrounding inflammatory microenvironment.

These infiltrated cells are able to activate apoptotic caspase proteolytic cascade through TNF receptor superfamily interactions (FasL/Fas and CD40/CD40L). The different members of this superfamily share common cell signaling pathways that mediate the activation of nuclear factor NF-kB and mitogen-activated protein kinases. In this case, CD40/CD40L interactions are known to induce the upregulation of Bcl-XL and Mcl1 expression and to mediate the activation of NF-кB (Hinz et al., 2001; Hong et al., 2000; Inoue et al., 2000; Kater et al., 2004; Lee et al., 1999; Metkar et al., 2001). CTLs are also able to trigger a second proapoptotic pathway through the protease granzyme B, which, once released from CTLs, is translocated into the target cell by perforin, where it activates the effector caspase cascade (Thome \& Tschopp, 2001). On the other hand, the wide variety of cytokines and chemokines present in HL tumoral tissue (IL-2, IL-4, IL-6, and IL-13), responsible for the massive influx of activated immune cells (Poppema et al., 1999), has been shown to regulate the expression of the various members of $\mathrm{Bcl} 2$ family, such as the antiapoptotic $\mathrm{Bcl} 2$ homologues $\mathrm{Bcl}-\mathrm{XL}$ and Mcl1 and the proapoptotic Bax (Akbar et al., 1996; Jourdan et al., 2000; Puthier et al., 1999; Song et al., 2002; Tang et al., 2002).

Likewise for the apoptotic markers, the physiologic signals present in the reactive microenvironment also interfere with components of the G1-CDK checkpoint (cyclin D3, CDK6, and p27) (Malumbres \& Barbacid, 2001; Wagner et al., 1998). The constitutively activated NF- $\kappa B$ has also been shown to induce changes in the expression of a set of proteins regulating cell cycle progression and gene transcription, including cyclin D1, p53, p16 INK4a, and p27KIP1 (Hinz et al., 2001; Sanchez-Beato et al., 2003). Cytotoxic cells are able to induce directly the permanent down-regulation of p27KIP1, probably as a consequence of increased degradation mediated by SKP2, a ubiquitin ligase for p27KIP1 (Blanchard et al., 1997; Ren et al., 2005; Wagner et al., 1998). Related with the heightened proliferative state in these tumors is the high level of expression of Bcl6, a multifunctional regulator that is able not only to down-regulate cyclin D2 and p27KIP1 expression (Shaffer et al., 2000) but also to repress Bcl-XL (Tang et al., 2002).

The presence of EBV was significantly associated with the overexpression of STAT1 and STAT3. STAT3 was found to be associated with a low infiltration of CD4 T lymphocytes and a high infiltration of activated cytotoxic cells. Although STAT1 is considered to be a potential tumor suppressor (promoting apoptosis), STAT3 is thought to be an oncogene because it leads to the activation of cyclin D1 and Bcl-XL expression and is involved in promoting cell cycle progression and cellular transformation and in preventing apoptosis (Calo et al., 2003).

The physiologic relevance of these relationships could be related to the different probabilities of survival of HL patients. Different sets of deregulated immune and tumoral genes have shown to be associated with a therapeutically unfavorable response in HL patients (Sanchez-Aguilera et al., 2006). For example, altered expression of bcl-2 and the bcl2 family of proteins (e.g., bcl-Xl, BAX) in H/RS cells may prevent apoptosis and explain resistance to treatment-induced apoptosis. Under these conditions, the concomitant analysis of the immune infiltrate and the apoptotic/proliferative pathways of tumoral cells should provide more accurate information about the specific molecular pathways critical for cancer 
cell growth. Possible molecules that interfere with these molecular links, particularly some enzymes representative of the immune metabolic state or tumoral cell cycle (SanchezAguilera et al., 2006), might be pharmaceutically manipulated and could be candidates for new therapeutic targets pertinent to patient care.

\section{HL in immunosuppressed patients}

Epidemiologic and molecular findings suggest that $\mathrm{cHL}$ is not a single disease but consists of more than one entity and may occur in different clinical settings. According to the acknowledged international literature (Swerdlow et al., 2008a), cHL arises either in the general population (Stein et al., 2008a) but also in the immunosuppressed host, specifically in HIV-infected individuals (Raphael et al., 2008), and in post-transplant patients, most often in renal post-transplant patients (Swerdlow et al., 2008c).

From a clinical perspective, HIV-infected HLs have some peculiarities. Firstly, it must be distinguished two eras, before and after the widespread use of highly active antiretroviral therapy (HAART) (Powles et al., 2009). Before HAART, HIV-HL patients were generally diagnosed with an aggressive presentation. Advanced stages were the rule at diagnosis with frequent involvement of extranodal sites, particularly bone marrow, liver and spleen. In addition, up to $95 \%$ of patients had systemic B symptoms when diagnosed, and consequently survival rates were extremely disappointing (Tirelli et al., 1995). Nevertheless, introduction of HAART have led to forms of presentation less aggressive, a dramatic reduction in the incidence of opportunistic infections, and finally it have allowed to complete curative treatment with chemotherapy in most of the patients (Carbone et al., 2009). Regarding chemotherapy, optimal treatment for HIV-HL has not been definitely established due to the relatively low incidence of this disease. However, little phase II studies with few patients have found that, in this modern HAART era, standard ABVD treatment may be safely administered with or without growth-colony stimulating factors (G-CSF) support (Xicoy et al., 2007), although some groups argue in favor of G-CSF introduction from the beginning to minimize risks. Prophylaxis against Pneumocystis jiroveci infection with trimethoprim-sulfamethoxazole is also strongly recommended in all these patients. Other more intensive regimens like BEACOPP or Stanford V with consolidation radiotherapy have been tested with acceptable results in terms of complete responses $(100 \%$ and $81 \%$, respectively), although a higher incidence of opportunistic infections and hematologic toxicity were registered. Finally, even the use of high dose chemotherapy and autologous stem cell transplantation have been demonstrated feasible in HL-HIV relapsed patients with curative purposes (Carbone et al., 2009). To conclude, it must be said that clinical outcomes of patients with HIV-HL has improved after HAART introduction, with higher curability rates when a combined antineoplastic and antiretroviral strategy is followed and completed.

Post-transplant lymphoproliferative disorders (PTLDs) are a heterogeneous group of monoclonal or polyclonal lymphoproliferative lesions that occur in immunosuppressed recipients after solid-organ or bone marrow transplantation. cHL occurs in the posttransplant setting, most often in renal transplant patients, is almost always EBV-positive and should complete the diagnostic criteria for cHL (Adams et al., 2009; Knight et al., 2009; Rohr et al., 2008; Swerdlow et al., 2008c). All patients received post-transplant 
immunosuppression and/or antiviral agents (Dharnidharka et al., 2004; Goyal et al., 1996; Krishnamurthy et al., 2010). Clinically, the majority of patients are men and all ages are affected. Generally, the time from transplant to the onset of the disease ranges from few months (4-6 months) to several years, with a median time of 113 months. Half cases presented as extranodal masses, especially in the liver or in the lung even if other extranodal sites (especially tonsil) can be involved. The best therapeutic approach is not well defined yet. Recently, rituximab has gained favor in the treatment of PTLD because of its targeting of CD20-positive B cells, with fairly promising results (Pham et al., 2002).

The iatrogenic lymphoproliferative disorders are lymphoid proliferations or lymphomas that arise in patients treated with immunosuppressive drugs. Among iatrogenic lymphoproliferative disorders, other than PTLD, there is an increase in frequency of cHL and lymphoid proliferations with Hodgkin-like features. Thus, lesions containing RS-like cells but do not fulfill the criteria of CHL, the so-called Hodgkin-like lesions, have been included in this setting (Gaulard et al., 2008). Because cHL has only recently been recognized as an iatrogenic complication, few cases have been reported in the medical literature (Gaulard et al., 2008).

\section{Antineoplastic therapy in HL: From classical to biological therapies}

Chemotherapy and radiotherapy remain the cornerstone of HL treatment. Especially, polychemotherapy schedules have increased the survival rates in these patients along the last decades. Nevertheless, up to $30 \%$ and $10 \%$ of patients will recur and die of HL in advanced and early disease respectively, and unlike what happened in non Hodgkin lymphomas, newer active compounds against HL have not been introduced in clinic since the early 1970s. In addition, patients exposed to chemotherapy and radiation fields are at highest risk of lethal second malignancies (Friedberg, 2011). Therefore it would be more than desirable having new therapeutic drugs and strategies for a better control of the disease and minimizing toxicity of therapy, especially when relapses occur.

\subsection{Conventional treatment}

Nowadays HL is considered one of the most oncological curable diseases, as a matter of fact of its extremely chemo and radiosensitivity. Among chemotherapy options, ABVD (doxorubicin, bleomycin, vinblastine and dacarbazine) represent the standard schedule for HL treatment in the majority of centers worldwide. However the management of advancedstage cHL is often predicated on the IPS, and thus escalated BEACOPP (bleomycin, etoposide, doxorubicin, cyclophosphamide, vincristine, procarbazine, prednisone) is another schedule to consider, especially in high-risk patients with IPS scores of 4 or greater (Diehl et al., 2003). Therefore, an apparently more effective initial treatment may be unattractive because of increased toxic effects (Connors, 2011) and highest risk of second malignancies, especially in relation with large radiation fields ( $\mathrm{Ng}$ et al., 2002).

Canellos et al showed in 1992 that ABVD was equally effective and less toxic than MOPP (mechlorethamine, vincristine, procarbazine, prednisone) or MOPP alternating with ABVD, and this has subsequently become the chemotherapy of choice worldwide (Canellos et al., 1992). Although standard ABVD can cure most of HL, advanced stage- high risk patients based on IPS still represent a major concern with EFS rates of $50 \%$ or less (Hasenclever \& 
Diehl, 1998). The HD9 trial conducted by Diehl et al showed that among patients with advanced-stage cHL, ABVD is insufficient for patients with an IPS of 4 or more (Diehl A et at, 2003). In this trial of the German Hodgkin Study Group (GHSG), 1,195 patients with advanced-stage HL were recruited and randomized between COPP-ABVD, standard BEACOPP, and escalated BEACOPP. For patients with an IPS of 4 or greater, the more intensive regimen improved the freedom from treatment failure from $59 \%$ to $82 \%$ and OS from $67 \%$ to $82 \%$. It is important to underscore that there was no significant difference for the more favorable groups. A 10-year update of this study confirms superiority of escalated BEACOPP over COPP-ABVD for the high-risk patients (Diehl et al., 2003). However, there is increased late toxicity with escalated BEACOPP, with more risk of sterility, infections and secondary leukaemia's, and thus universal application of this schedule for advanced-stage disease remain difficult to implement.

In addition of chemotherapy, radiotherapy is another treatment modality frequently used in HL. It is generally indicated in early disease, regardless of the favorable/unfavorable stratification, and when bulky disease is present, or there remain residual foci of disease after chemotherapy in advanced HL.

\subsection{Impact of chemotherapy and radiotherapy on tumoral microenvironment}

In the last few years, many interesting data have emerged about the enormous impact of the antineoplastic treatments into the immune microenvironment of the tumors, which demonstrate a sort of cancer vaccination effect (Haynes et al., 2008). In this sense, chemotherapeutics like anthracyclines (included in all of the upfront standard treatments of $\mathrm{HL}$ ) and radiotherapy seem to induce a type of apoptotic death via calreticulin exposure and release of the pro-inflammatory factor High Mobility Group Box-1 (HMGB1) with well known immune stimulating properties (Tesniere et al., 2008).

Anthracyclines can induce a highly potent immune response by increasing antigen (neoantigens) threshold and presentation (via antigen presenting cells), with enhancement of T-cell response and generation of memory $T$ cells (Obeid et al., 2007a). Other chemotherapeutics like cyclophosphamide, etoposide and taxanes have also proved to have an immunogenic effect in preclinical models (Tsavaris et al., 2002), however evidence is scarce and further investigation is required.

These new concepts might serve to consider chemotherapeutics like anthracyclines as less empirical and more specific drugs, and thus it would be desirable to customize chemotherapies taking into account their potential effects on microenvironment. In this sense, there is an interesting field of clinical research to discover that may combine classical $\mathrm{CT}$ agents with immunogenic effects with boosting costimulators molecules like cytokines (GM-CSF, IL2) (de la Cruz-Merino et al., 2008). Specifically in the case of the anthracycline's effect on cancer cells, the calreticulin exposure do not induce DC maturation which is, on the contrary, one of the main effects of cytokines like GM-CSF that induce selective DC maturation and activation, giving a strong rationale to combine these two therapeutic modalities (anthracyclines and GM-CSF). These combinatorial strategies may eventually sustain immunogenic effect of tumoral cell death. Regarding to this, biomarkers of immune activity should be of the greatest interest, in order to serve as proof of principle of efficacy with an earlier detection of the eventual benefits of oncological treatments in patients. 
Furthermore, monitoring changes detected during oncological treatments in blood samples, especially in immunophenotype, regulatory $\mathrm{T}$ cells amount and TCD8/regulatory $\mathrm{T}$ cells ratio, may represent interesting biomarkers to analyze and validate in the future.

As happen with chemotherapy, the intrinsic radiosensitivity of malignant lymphocytes is extremely high. Although the underlying mechanisms which explain it are not fully elucidated, recently new evidence is emerging about some changes induced by radiation at a molecular level, which may provoke a type of cell death highly immunogenic (Formenti \& Demaria, 2009). Ionising radiation has different immune effects regarding the dose administered, and while in the case of low doses the final effect is mostly protumorigenic, at higher doses with cytotoxic activity, cell death may induce tumoral neoantigens which can be embraced by DC, and thus activate an effective adaptive immune response (Apetoh et al., 2007). As with anthracyclines, the two critical mediators of this process seem to be translocation of calreticulin to the cell surface and release of HMGB1 by the dying cells (Formenti \& Demaria, 2009). Both of them trigger danger signals which activate immune mechanisms. In addition, surviving cancer cells after radiation show increased expression of death receptors, adhesion molecules (ICAM-1) and major histocompatibility complex class I (MHC-I), which activate APCs (Obeid et al., 2007b).

To conclude, some groups argue that these immune effects are the major determinants of the therapeutical success of the antineoplastic treatments in oncological diseases, including HL.

\subsection{Modern therapeutic approaches targeting the tumor microenvironment}

Apart from chemotherapy and radiotherapy, other biological compounds with significant effects upon tumor microenvironment like unconjugated and conjugated monoclonal antibodies, radioimmunconjugates, immunotoxins and novel immunomodulatory compounds like lenalidomide are under clinical investigation, and at this moment they represent the most promising therapeutical strategies in HL. Recently, Kasamon et al revised this topic (Kasamon \& Ambinder, 2008) and pointed out three major HL therapeutic targets: EBV, CD20 and CD30.

As previously cited, up to $40-60 \%$ of cHL might be associated with EBV and thus some EBV antigens expressed on HL cells like latent membrane protein 1 and 2 (LMP1 and LMP2) have been postulated as eventual immunotherapeutic targets. Some interesting results have been obtained with the use of adoptive cellular immunotherapy with EBV-specific CTL among patients with EBV-associated posttransplant lymphoproliferative diseases (Haque T et al., 2007), rendering a proof of principle of activity for this approach. In a small study of 16 patients with relapsed or high risk $\mathrm{EBV}^{+}$lymphoproliferative diseases that included cases of HL, infusions of autologous LMP2- specific CTL induced clinical responses with tumor regression in 5 of 6 patients with previously detectable tumor (Lucas et al., 2004).

After elucidation of the B cell origin of H/RS in classical HL, targeting B cell antigens on HL has gained renewed interest. Specifically in classical HL, the monoclonal antibody antiCD20 Rituximab has shown activity as single agent or combined with chemotherapies like ABVD and gemcitabine in different clinical settings (Kasamon \& Ambinder, 2008). Impact of rituximab on tumor microenviroment by depleting benign $\mathrm{CD}_{20} 0^{+}$cells, is postulated as the main antineoplastic mechanism of action of this drug in HL, independently of CD20 expresssion on the H/RS cells. Rituximab has also been tested in the uncommon nodular 
lymphocyte predominant Hodgkin lymphoma, with impressive clinical results (Rehwald et al., 2003; Ekstrand et al., 2003) that merit further investigation.

Among new molecular targets in HL, the member of the tumor necrosis factor (TNF)receptor family CD30 merits special consideration. CD30 is expressed abundantly on RS cells of HL, and in other numerous lymphoid malignancies of B-, T-, and natural killer (NK)cell origin (Deutsch et al., 2011). Regarding its biological activity CD30 has pleiotropic biologic functions, being capable of promoting cell proliferation and survival as well as inducing antiproliferative responses and cell death. Final effects of CD30 activation seem largely dependent on the microenvironment context (Deutsch et al., 2011). Unconjugated anti-CD30 antibodies have been tested in phase I and II studies showing limited clinical activity (Kasamon \& Ambinder, 2008). On the contrary, another attractive approach as it is the use of antibody-drug conjugates (ADCs) have rendered better results.

Brentuximab vedotin (SGN-35) is an ADC consisting of chimeric anti-CD30 antibody cAC10 (SGN-30) conjugated to the tubulin destabilizer monomethylauristatin E (MMAE) (Okeley et al., 2010). In an initial phase I dose escalation study, brentuximab vedotin was administered at a dose of $0.1-3.6 \mathrm{mg} / \mathrm{kg}$ every 3 weeks to 45 patients with relapsed or refractory CD30positive lymphomas, primarily HL and ALCL (Younes et al., 2010). Brentuximab vedotin was well tolerated and associated mainly with grade 1 or 2 adverse events including neutropenia and peripheral neuropathy. Objective response was observed in $17(38 \%)$ patients, including 11 (24\%) complete remissions, with a median duration of response of 9.7 months. Tumor regression was observed in $86 \%$ of patients. The maximum tolerated dose was $1.8 \mathrm{mg} / \mathrm{kg}$, and of 12 patients who received this dose, six patients (50\%) had an objective response (Younes A et al, 2010). A second phase I study, with weekly brentuximab vedotin resulted in an objective response rate of $59 \%$ and rapid median time to response. Anti-tumor activity was similar to that observed for dosing once every 3 weeks. However, significant peripheral neuropathy was observed with continued weekly dosing, so the administration every 3 weeks was preferred for phase II studies (Deutsch et al., 2011).

Clearly, brentuximab vedotin is an exciting new agent in the setting of relapsed HL and other lymphoid neoplasms CD30 ${ }^{+}$. Multiple clinical trials are ongoing including different clinical settings and combinations with chemotherapy, in order to find the safer and more successful way of administering this drug.

\section{Body's own power protection challenges in HL}

Evidences in the literature suggest that targeting elements of the tumor microenvironment, or signaling pathways in tumor cells activated as a consequence of stromal interactions, may prove a useful therapeutic strategy to prevent tumor development and progression. However, given the tumor cells' ability to circumvent various therapeutic agents when given as monotherapy, the success of these agents is likely to be seen when used in combination with existing treatments.

Apart from the infiltrating immune competent cells, the complex tissue network of the tumor microenvironment is also formed by neoangiogenesis, stromal cells, and a differentiated and specific extracellular matrix. Among stromal cells, there are macrophages-derived from hematopoietic stem cells, fibroblasts, adipocytes, and osteoblasts. In order to delay or circumvent tumor progression, a number of strategies are 
being developed to disrupt tumor-stroma interactions (Hiscox et al., 2011). Macrophages and fibroblasts within the tumor microenvironment present an important point for therapeutic intervention by using agents which reverse their phenotype or block key growth factor receptors (Allavena et al., 2005; Banciu et al., 2008; Hagemann et al., 2008; Hiscox et al., 2011; Karin \& Greten, 2005). On the other hand, the regulation of adhesion between cancer cells and the surrounding matrix by different kind of integrins activates tumor cell signaling pathways that result in growth progression, invasion and migration (Green et al., 2009; Hiscox et al., 2011; Inoki et al., 2002; Kim et al., 2009; Parsons et al., 2008; Stupp \& Ruegg, 2007).

The different immunotherapeutic models that have been tested for the treatment of HL include unconjugated monoclonal antibodies (Ansell et al., 2007; Bartlett et al., 2008; Klimm et al., 2005), immunotoxins (Falini et al., 1992; Kreitman et al., 2000), radioimmunoconjugates (Klimm et al., 2005; Schnell et al., 2005) and, most recently, immunomodulatory compounds (Bollard et al., 2004; Borchmann et al., 2002; Davies et al., 2001; Hartmann et al., 2001; Hartmann et al., 1997; Maier \& Hammond, 2006; Roskrow et al., 1998). Some strategies, in particular radioimmunotherapeutic approaches and immunotoxins have already shown significant effectivity (Friedberg, 2011). First experiences with relatively non-toxic immunomodulatory compounds have implemented a whole new kind of immunotherapy in NLPHL where the anti-CD20-antibody Rituximab might be the future effective but less toxic treatment (Ekstrand et al., 2003; Schulz et al., 2008).

The integration of the new biologic markers evaluated in HL, that clearly driving force for an abnormal local and systemic antitumor immunity in HL, make of HL an ideal candidate for immunotherapeutic strategies (Rathore \& Kadin, 2010; Younes, 2009). The pro-survival and pro-death receptors expressed by tumoral cells are currently being explored for novel treatment strategies by using a variety of naked and conjugated monoclonal antibodies. Furthermore, signaling pathways triggered by these receptors and other intracellular proteins can now be therapeutically inhibited by a variety of small molecules. Nowadays, the present challenge remains to know the best way to implement immunotherapeutic concepts into the current treatment concepts of HL in order to conserve or even improve the good long term survival in these patients and to reduce toxicity and long-term side-effects.

\section{Conclusion}

Although the relatively good prognosis and high current overall cure rate of cHL, it is important to underscore that clinicobiological factors still remain the main information to guide treatment policies in HL. Due to the fact that this disease is commonly diagnosed in young population, and antineoplastic treatments may induce worrying iatrogenic consequences in terms of secondary tumors (solid and hematologic malignancies), cardiopathies or respiratory long-term morbidities among others, it is indispensable to administer always the minimum effective and curative therapy. In this sense, beyond the well known clinical risk factors, interim information in the course of chemotherapy of PET scans will probably aid in the next future to apply a less empiric and more tailored and personalized treatment. Since early 90's ABVD schedule represent the standard treatment of HL for curative purposes worldwide and little has changed in clinical practice in the last two decades. However there is room for improvement since a significant percentage of patients will ultimately relapse after successful treatment. 
The recent research activities led to a better understanding of the phenotype, molecular characteristics, histogenesis, and possible mechanisms of HL lymphomagenesis. There is complete consensus on the B-cell derivation of the tumor in most cases, and on the relevance of EBV infection and defective cytokinesis in at least a proportion of patients. The influence of the cellular components of the microenvironment and that of the elaborate network of interactions they produce, on the clinical course of HL, has progressively emerged over the past decades. The expression of a variety of cytokines and chemokines by the tumoral cells is believed to drive an abnormal immune response and additional factors secreted by reactive cells in the microenvironment help to maintain the inflammatory milieu. In these conditions, tumoral cells manipulate microenvironment, permitting them to develop their malignant phenotype fully and evade host immune response attack. The interplay between tumoral cells and the reactive microenvironment determines not only the histological morphology and classification but also the clinicopathological features and prognosis of these patients. Genes and proteins expression signatures derived from immune cells have demonstrated to correlate well with response to treatments the outcome of HL patients respectively. This could be critical to the development of adoptive T-cell therapies that target the virus or different cell components of HL microenvironment. In aggressive HL, the development of prognostic systems modelled on the integration of biologic prognostic markers appears essential for more appropriate risk stratification.

New knowledge about impact of chemotherapy upon microenvironment has changed old paradigms, conferring to some cytotoxic agents like anthracyclines immunogenic properties that can explain the final mechanism of action of these drugs. These discoveries are extremely important since give a strong rationale to exploit this activity in the context of combinatorial strategies that might include other immunogenic agents like cytokines and monoclonal antibodies, among others. Therefore, it is conceivable to hypothesize that chemotherapy can still improve its efficacy in HL in the next future. Furthermore, recently new molecules have shown impressive clinical activity in HL. It is the case of the antibodydrug conjugate anti-CD30 brentuximab vedotin that have obtained very promising results in relapsed $\mathrm{CD} 30^{+}$lymphomas, and thus has given place to ongoing phase III confirmatory studies.

To summarize, the incorporation of PET scans in HL diagnostic and follow-up algorithms, the widespread use of the new prognostic molecular and biological factors at diagnosis, the new highly effective molecules and the recent knowledge regarding chemotherapy effects on microenviroment, permit forsee a different and customized therapeutical approach to HL in the next future.

\section{References}

Abele, M.C.; Valente, G.; Kerim, S.; Navone, R.; Onesti, P.; Chiusa, L.; Resegotti, L. \& Palestro, G. (1997). Significance of cell proliferation index in assessing histological prognostic categories in Hodgkin's disease. An immunohistochemical study with Ki67 and MIB-1 monoclonal antibodies. Haematologica, Vol.82, No.3, pp. 281-285, 0390-6078

Adam, C.; King, S.; Allgeier, T.; Braumuller, H.; Luking, C.; Mysliwietz, J.; Kriegeskorte, A.; Busch, D.H.; Rocken, M. \& Mocikat, R. (2005). DC-NK cell cross talk as a novel 
CD4+ T-cell-independent pathway for antitumor CTL induction. Blood, Vol.106, No.1, pp. 338-344, 0006-4971

Adam, J.K.; Odhav, B. \& Bhoola, K.D. (2003). Immune responses in cancer. Pharmacol Ther, Vol.99, No.1, pp. 113-132, 0163-7258

Adams, H.; Campidelli, C.; Dirnhofer, S.; Pileri, S.A. \& Tzankov, A. (2009). Clinical, phenotypic and genetic similarities and disparities between post-transplant and classical Hodgkin lymphomas with respect to therapeutic targets. Expert Opin Ther Targets, Vol.13, No.10, pp. 1137-1145, 1744-7631

Akbar, A.N.; Borthwick, N.J.; Wickremasinghe, R.G.; Panayoitidis, P.; Pilling, D.; Bofill, M.; Krajewski, S.; Reed, J.C. \& Salmon, M. (1996). Interleukin-2 receptor common gamma-chain signaling cytokines regulate activated $\mathrm{T}$ cell apoptosis in response to growth factor withdrawal: selective induction of anti-apoptotic (bcl-2, bcl-xL) but not pro-apoptotic (bax, bcl-xS) gene expression. Eur J Immunol, Vol.26, No.2, pp. 294-299, 0014-2980

Aldinucci, D.; Lorenzon, D.; Cattaruzza, L.; Pinto, A.; Gloghini, A.; Carbone, A. \& Colombatti, A. (2008). Expression of CCR5 receptors on Reed-Sternberg cells and Hodgkin lymphoma cell lines: involvement of CCL5/Rantes in tumor cell growth and microenvironmental interactions. Int J Cancer, Vol.122, No.4, pp. 769-776, 10970215

Aldinucci, D.; Olivo, K.; Lorenzon, D.; Poletto, D.; Gloghini, A.; Carbone, A. \& Pinto, A. (2005). The role of interleukin-3 in classical Hodgkin's disease. Leuk Lymphoma, Vol.46, No.3, pp. 303-311, 1042-8194

Allavena, P.; Signorelli, M.; Chieppa, M.; Erba, E.; Bianchi, G.; Marchesi, F.; Olimpio, C.O.; Bonardi, C.; Garbi, A.; Lissoni, A.; de Braud, F.; Jimeno, J. \& D'Incalci, M. (2005). Anti-inflammatory properties of the novel antitumor agent yondelis (trabectedin): inhibition of macrophage differentiation and cytokine production. Cancer Res, Vol.65, No.7, pp. 2964-2971, 0008-5472

Alvaro-Naranjo, T.; Lejeune, M.; Salvado-Usach, M.T.; Bosch-Princep, R.; Reverter-Branchat, G.; Jaen-Martinez, J. \& Pons-Ferre, L.E. (2005). Tumor-infiltrating cells as a prognostic factor in Hodgkin's lymphoma: a quantitative tissue microarray study in a large retrospective cohort of 267 patients. Leuk Lymphoma, Vol.46, No.11, pp. 1581-1591, 1042-8194

Alvaro, T.; de la Cruz-Merino, L.; Henao-Carrasco, F.; Villar Rodriguez, J.L.; Vicente Baz, D.; Codes Manuel de Villena, M. \& Provencio, M. (2010). Tumor microenvironment and immune effects of antineoplastic therapy in lymphoproliferative syndromes. $J$ Biomed Biotechnol, Vol.2010, pp. , 1110-7251

Alvaro, T.; Lejeune, M.; Escriva, P.; Pons, L.E.; Bosch, R.; Jaen, J.; Lopez, C.; Salvado, M.T. \& de Sanjose, S. (2009). Appraisal of immune response in lymphoproliferative syndromes: a systematic review. Crit Rev Oncol Hematol, Vol.70, No.2, pp. 103-113, 1879-0461

Alvaro, T.; Lejeune, M.; Garcia, J.F.; Salvado, M.T.; Lopez, C.; Bosch, R.; Jaen, J.; Escriva, P. \& Pons, L.E. (2008). Tumor-infiltrated immune response correlates with alterations in the apoptotic and cell cycle pathways in Hodgkin and Reed-Sternberg cells. Clin Cancer Res, Vol.14, No.3, pp. 685-691, 1078-0432

Alvaro, T.; Lejeune, M.; Salvado, M.T.; Bosch, R.; Garcia, J.F.; Jaen, J.; Banham, A.H.; Roncador, G.; Montalban, C. \& Piris, M.A. (2005). Outcome in Hodgkin's 
lymphoma can be predicted from the presence of accompanying cytotoxic and regulatory T cells. Clin Cancer Res, Vol.11, No.4, pp. 1467-1473, 1078-0432

Anagnostopoulos, I.; Hansmann, M.L.; Franssila, K.; Harris, M.; Harris, N.L.; Jaffe, E.S.; Han, J.; van Krieken, J.M.; Poppema, S.; Marafioti, T.; Franklin, J.; Sextro, M.; Diehl, V. \& Stein, H. (2000). European Task Force on Lymphoma project on lymphocyte predominance Hodgkin disease: histologic and immunohistologic analysis of submitted cases reveals 2 types of Hodgkin disease with a nodular growth pattern and abundant lymphocytes. Blood, Vol.96, No.5, pp. 1889-1899, 0006-4971

Ansell, S.M.; Horwitz, S.M.; Engert, A.; Khan, K.D.; Lin, T.; Strair, R.; Keler, T.; Graziano, R.; Blanset, D.; Yellin, M.; Fischkoff, S.; Assad, A. \& Borchmann, P. (2007). Phase I/II study of an anti-CD30 monoclonal antibody (MDX-060) in Hodgkin's lymphoma and anaplastic large-cell lymphoma. J Clin Oncol, Vol.25, No.19, pp. 2764-2769, 1527-7755

Ansell, S.M.; Stenson, M.; Habermann, T.M.; Jelinek, D.F. \& Witzig, T.E. (2001). Cd4+ T-cell immune response to large B-cell non-Hodgkin's lymphoma predicts patient outcome. J Clin Oncol, Vol.19, No.3, pp. 720-726, 0732-183X

Apetoh, L.; Ghiringhelli, F.; Tesniere, A.; Obeid, M.; Ortiz, C.; Criollo, A.; Mignot, G.; Maiuri, M.C.; Ullrich, E.; Saulnier, P.; Yang, H.; Amigorena, S.; Ryffel, B.; Barrat, F.J.; Saftig, P.; Levi, F.; Lidereau, R.; Nogues, C.; Mira, J.P.; Chompret, A.; Joulin, V.; ClavelChapelon, F.; Bourhis, J.; Andre, F.; Delaloge, S.; Tursz, T.; Kroemer, G. \& Zitvogel, L. (2007). Toll-like receptor 4-dependent contribution of the immune system to anticancer chemotherapy and radiotherapy. Nat Med, Vol.13, No.9, pp. 1050-1059, 1078-8956

Ascani, S.; Zinzani, P.L.; Gherlinzoni, F.; Sabattini, E.; Briskomatis, A.; de Vivo, A.; Piccioli, M.; Fraternali Orcioni, G.; Pieri, F.; Goldoni, A.; Piccaluga, P.P.; Zallocco, D.; Burnelli, R.; Leoncini, L.; Falini, B.; Tura, S. \& Pileri, S.A. (1997). Peripheral T-cell lymphomas. Clinico-pathologic study of 168 cases diagnosed according to the R.E.A.L. Classification. Ann Oncol, Vol.8, No.6, pp. 583-592, 0923-7534

Atkinson, E.A. \& Bleackley, R.C. (1995). Mechanisms of lysis by cytotoxic T cells. Crit Rev Immunol, Vol.15, No.3-4, pp. 359-384, 1040-8401

Axdorph, U.; Sjoberg, J.; Grimfors, G.; Landgren, O.; Porwit-MacDonald, A. \& Bjorkholm, M. (2000). Biological markers may add to prediction of outcome achieved by the International Prognostic Score in Hodgkin's disease. Ann Oncol, Vol.11, No.11, pp. 1405-1411, 0923-7534

Azuma, T.; Takahashi, T.; Kunisato, A.; Kitamura, T. \& Hirai, H. (2003). Human CD4+ CD25+ regulatory $\mathrm{T}$ cells suppress NKT cell functions. Cancer Res, Vol.63, No.15, pp. 4516-4520, 0008-5472

Bai, M.; Papoudou-Bai, A.; Kitsoulis, P.; Horianopoulos, N.; Kamina, S.; Agnantis, N.J. \& Kanavaros, P. (2005). Cell cycle and apoptosis deregulation in classical Hodgkin lymphomas. In Vivo, Vol.19, No.2, pp. 439-453, 0258-851X

Bai, M.; Tsanou, E.; Agnantis, N.J.; Chaidos, A.; Dimou, D.; Skyrlas, A.; Dimou, S.; Vlychou, M.; Galani, V. \& Kanavaros, P. (2003). Expression of cyclin D3 and cyclin E and identification of distinct clusters of proliferation and apoptosis in diffuse large Bcell lymphomas. Histol Histopathol, Vol.18, No.2, pp. 449-457, 0213-3911

Banciu, M.; Metselaar, J.M.; Schiffelers, R.M. \& Storm, G. (2008). Antitumor activity of liposomal prednisolone phosphate depends on the presence of functional tumor- 
associated macrophages in tumor tissue. Neoplasia, Vol.10, No.2, pp. 108-117, 14765586

Bargou, R.C.; Emmerich, F.; Krappmann, D.; Bommert, K.; Mapara, M.Y.; Arnold, W.; Royer, H.D.; Grinstein, E.; Greiner, A.; Scheidereit, C. \& Dorken, B. (1997). Constitutive nuclear factor-kappaB-RelA activation is required for proliferation and survival of Hodgkin's disease tumor cells. J Clin Invest, Vol.100, No.12, pp. 2961-2969, 00219738

Barth, T.F.; Martin-Subero, J.I.; Joos, S.; Menz, C.K.; Hasel, C.; Mechtersheimer, G.; Parwaresch, R.M.; Lichter, P.; Siebert, R. \& Mooller, P. (2003). Gains of 2p involving the REL locus correlate with nuclear c-Rel protein accumulation in neoplastic cells of classical Hodgkin lymphoma. Blood, Vol.101, No.9, pp. 3681-3686, 0006-4971

Bartlett, N.L.; Younes, A.; Carabasi, M.H.; Forero, A.; Rosenblatt, J.D.; Leonard, J.P.; Bernstein, S.H.; Bociek, R.G.; Lorenz, J.M.; Hart, B.W. \& Barton, J. (2008). A phase 1 multidose study of SGN-30 immunotherapy in patients with refractory or recurrent CD30+ hematologic malignancies. Blood, Vol.111, No.4, pp. 1848-1854, 0006-4971, 0006-4971

Baumforth, K.R.; Birgersdotter, A.; Reynolds, G.M.; Wei, W.; Kapatai, G.; Flavell, J.R.; Kalk, E.; Piper, K.; Lee, S.; Machado, L.; Hadley, K.; Sundblad, A.; Sjoberg, J.; Bjorkholm, M.; Porwit, A.A.; Yap, L.F.; Teo, S.; Grundy, R.G.; Young, L.S.; Ernberg, I.; Woodman, C.B. \& Murray, P.G. (2008). Expression of the Epstein-Barr virusencoded Epstein-Barr virus nuclear antigen 1 in Hodgkin's lymphoma cells mediates Up-regulation of CCL20 and the migration of regulatory T cells. Am J Pathol, Vol.173, No.1, pp. 195-204, 1525-2191

Berke, G. (1995). The CTL's kiss of death. Cell, Vol.81, No.1, pp. 9-12, 0092-8674

Bladergroen, B.A.; Meijer, C.J.; ten Berge, R.L.; Hack, C.E.; Muris, J.J.; Dukers, D.F.; Chott, A.; Kazama, Y.; Oudejans, J.J.; van Berkum, O. \& Kummer, J.A. (2002). Expression of the granzyme B inhibitor, protease inhibitor 9 , by tumor cells in patients with nonHodgkin and Hodgkin lymphoma: a novel protective mechanism for tumor cells to circumvent the immune system? Blood, Vol.99, No.1, pp. 232-237.

Blanchard, D.A.; Affredou, M.T. \& Vazquez, A. (1997). Modulation of the p27kip1 cyclindependent kinase inhibitor expression during IL-4-mediated human B cell activation. J Immunol, Vol.158, No.7, pp. 3054-3061, 0022-1767

Bollard, C.M.; Aguilar, L.; Straathof, K.C.; Gahn, B.; Huls, M.H.; Rousseau, A.; Sixbey, J.; Gresik, M.V.; Carrum, G.; Hudson, M.; Dilloo, D.; Gee, A.; Brenner, M.K.; Rooney, C.M. \& Heslop, H.E. (2004). Cytotoxic T lymphocyte therapy for Epstein-Barr virus+ Hodgkin's disease. J Exp Med, Vol.200, No.12, pp. 1623-1633, 0022-1007

Borchmann, P.; Schnell, R.; Fuss, I.; Manzke, O.; Davis, T.; Lewis, L.D.; Behnke, D.; Wickenhauser, C.; Schiller, P.; Diehl, V. \& Engert, A. (2002). Phase 1 trial of the novel bispecific molecule $\mathrm{H} 22 \times \mathrm{Ki}-4$ in patients with refractory Hodgkin lymphoma. Blood, Vol.100, No.9, pp. 3101-3107, 0006-4971

Bosch Princep, R.; Lejeune, M.; Salvado Usach, M.T.; Jaen Martinez, J.; Pons Ferre, L.E. \& Alvaro Naranjo, T. (2005). Decreased number of granzyme B+ activated CD8+ cytotoxic $\mathrm{T}$ lymphocytes in the inflammatory background of HIV-associated Hodgkin's lymphoma. Ann Hematol, Vol.84, No.10, pp. 661-666, 0939-5555

Bosshart, H. (2002). T helper cell activation in B-cell lymphomas. J Clin Oncol, Vol.20, No.12, pp. 2904-2905; author reply 2905, 0732-183X 
Brauninger, A.; Schmitz, R.; Bechtel, D.; Renne, C.; Hansmann, M.L. \& Kuppers, R. (2006). Molecular biology of Hodgkin's and Reed/Sternberg cells in Hodgkin's lymphoma. Int J Cancer, Vol.118, No.8, pp. 1853-1861, 0020-7136

Brink, A.A.; Oudejans, J.J.; van den Brule, A.J.; Kluin, P.M.; Horstman, A.; Ossenkoppele, G.J.; van Heerde, P.; Jiwa, M. \& Meijer, C.J. (1998). Low p53 and high bcl-2 expression in Reed-Sternberg cells predicts poor clinical outcome for Hodgkin's disease: involvement of apoptosis resistance? Mod Pathol, Vol.11, No.4, pp. 376-383, 0893-3952

Burnet, M. (1957). Cancer: a biological approach. III. Viruses associated with neoplastic conditions. IV. Practical applications. Br Med J, Vol.1, No.5023, pp. 841-847, 00071447

Burns, E.A. \& Leventhal, E.A. (2000). Aging, immunity, and cancer. Cancer Control, Vol.7, No.6, pp. 513-522, 1073-2748

Calo, V.; Migliavacca, M.; Bazan, V.; Macaluso, M.; Buscemi, M.; Gebbia, N. \& Russo, A. (2003). STAT proteins: from normal control of cellular events to tumorigenesis. J Cell Physiol, Vol.197, No.2, pp. 157-168, 0021-9541

Camilleri-Broet, S.; Ferme, C.; Berger, F.; Lepage, E.; Bain, S.; Briere, J.; Marmey, B.; Gaulard, P. \& Audouin, J. (2004). TiA1 in advanced-stage classical Hodgkin's lymphoma: no prognostic impact for positive tumour cells or number of cytotoxic cells. Virchows Arch, Vol.445,Nº4, pp. 344-346, 0945-6317

Campo, E.; Swerdlow, S.H.; Harris, N.L.; Pileri, S.; Stein, H. \& Jaffe, E.S. (2011). The 2008 WHO classification of lymphoid neoplasms and beyond: evolving concepts and practical applications. Blood, Vol.117, No.19, pp. 5019-5032, 1528-0020

Canellos, G.P.; Anderson, J.R.; Propert, K.J.; Nissen, N.; Cooper, M.R.; Henderson, E.S.; Green, M.R.; Gottlieb, A. \& Peterson, B.A. (1992). Chemotherapy of advanced Hodgkin's disease with MOPP, ABVD, or MOPP alternating with ABVD. $N$ Engl J Med, Vol.327, No.21, pp. 1478-1484, 0028-4793

Carbone, A.; Gloghini, A.; Serraino, D. \& Spina, M. (2009). HIV-associated Hodgkin lymphoma. Curr Opin HIV AIDS, Vol.4, No.1, pp. 3-10, 1746-6318

Casey, T.T.; Olson, S.J.; Cousar, J.B. \& Collins, R.D. (1989). Immunophenotypes of ReedSternberg cells: a study of 19 cases of Hodgkin's disease in plastic-embedded sections. Blood, Vol.74, No.8, pp. 2624-2628, 0006-4971

Chetaille, B.; Bertucci, F.; Finetti, P.; Esterni, B.; Stamatoullas, A.; Picquenot, J.M.; Copin, M.C.; Morschhauser, F.; Casasnovas, O.; Petrella, T.; Molina, T.; Vekhoff, A.; Feugier, P.; Bouabdallah, R.; Birnbaum, D.; Olive, D. \& Xerri, L. (2009). Molecular profiling of classical Hodgkin lymphoma tissues uncovers variations in the tumor microenvironment and correlations with EBV infection and outcome. Blood, Vol.113, No.12, pp. 2765-3775, 1528-0020

Chimienti, E.; Spina, M. \& Gastaldi, R. (2008). Clinical characteristics and outcome of 290 patients (pts) with Hodgkin's disease and HIV infection (HD-HIV) in pre and HAART (highly active antiretroviral therapy) era. . Ann Oncol Vol.9 pp. iv136

Connors, J.M. (2005). State-of-the-art therapeutics: Hodgkin's lymphoma. J Clin Oncol, Vol.23, No.26, pp. 6400-6408, 0732-183X

Connors, J.M. (2011). Hodgkin's lymphoma--the great teacher. N Engl J Med, Vol.365, No.3, pp. 264-265, 1533-4406 
Curiel, T.J.; Coukos, G.; Zou, L.; Alvarez, X.; Cheng, P.; Mottram, P.; Evdemon-Hogan, M.; Conejo-Garcia, J.R.; Zhang, L.; Burow, M.; Zhu, Y.; Wei, S.; Kryczek, I.; Daniel, B.; Gordon, A.; Myers, L.; Lackner, A.; Disis, M.L.; Knutson, K.L.; Chen, L. \& Zou, W. (2004). Specific recruitment of regulatory $\mathrm{T}$ cells in ovarian carcinoma fosters immune privilege and predicts reduced survival. Nat Med, Vol.10, No.9, pp. 942949, 1078-8956

Davies, F.E.; Raje, N.; Hideshima, T.; Lentzsch, S.; Young, G.; Tai, Y.T.; Lin, B.; Podar, K.; Gupta, D.; Chauhan, D.; Treon, S.P.; Richardson, P.G.; Schlossman, R.L.; Morgan, G.J.; Muller, G.W.; Stirling, D.I. \& Anderson, K.C. (2001). Thalidomide and immunomodulatory derivatives augment natural killer cell cytotoxicity in multiple myeloma. Blood, Vol.98, No.1, pp. 210-216, 0006-4971

de la Cruz-Merino, L.; Grande-Pulido, E.; Albero-Tamarit, A. \& Codes-Manuel de Villena, M.E. (2008). Cancer and immune response: old and new evidence for future challenges. Oncologist, Vol.13, No.12, pp. 1246-1254, 1549-490X

de Visser, K.E. \& Kast, W.M. (1999). Effects of TGF-beta on the immune system: implications for cancer immunotherapy. Leukemia, Vol.13, No.8, pp. 1188-1199, 0887-6924

Deutsch, Y.E.; Tadmor, T.; Podack, E.R. \& Rosenblatt, J.D. (2011). CD30: an important new target in hematologic malignancies. Leuk Lymphoma, Vol.52, No.9, pp. 1641-1654, 1029-2403

Devilard, E.; Bertucci, F.; Trempat, P.; Bouabdallah, R.; Loriod, B.; Giaconia, A.; Brousset, P.; Granjeaud, S.; Nguyen, C.; Birnbaum, D.; Birg, F.; Houlgatte, R. \& Xerri, L. (2002). Gene expression profiling defines molecular subtypes of classical Hodgkin's disease. Oncogene, Vol.21, No.19, pp. 3095-3102, 0950-9232

Dharnidharka, V.R.; Douglas, V.K.; Hunger, S.P. \& Fennell, R.S. (2004). Hodgkin's lymphoma after post-transplant lymphoproliferative disease in a renal transplant recipient. Pediatr Transplant, Vol.8, No.1, pp. 87-90, 1397-3142

Diehl, V.; Franklin, J.; Pfreundschuh, M.; Lathan, B.; Paulus, U.; Hasenclever, D.; Tesch, H.; Herrmann, R.; Dorken, B.; Muller-Hermelink, H.K.; Duhmke, E. \& Loeffler, M. (2003). Standard and increased-dose BEACOPP chemotherapy compared with COPP-ABVD for advanced Hodgkin's disease. $N$ Engl J Med, Vol.348, No.24, pp. 2386-2395, 1533-4406

Diehl, V.; Sextro, M.; Franklin, J.; Hansmann, M.L.; Harris, N.; Jaffe, E.; Poppema, S.; Harris, M.; Franssila, K.; van Krieken, J.; Marafioti, T.; Anagnostopoulos, I. \& Stein, H. (1999). Clinical presentation, course, and prognostic factors in lymphocytepredominant Hodgkin's disease and lymphocyte-rich classical Hodgkin's disease: report from the European Task Force on Lymphoma Project on LymphocytePredominant Hodgkin's Disease. J Clin Oncol, Vol.17, No.3, pp. 776-783, 0732-183X

Diehl, V.; Thomas, R.K. \& Re, D. (2004). Part II: Hodgkin's lymphoma--diagnosis and treatment. Lancet Oncol, Vol.5, No.1, pp. 19-26, 1470-2045

Dutton, A.; Reynolds, G.M.; Dawson, C.W.; Young, L.S. \& Murray, P.G. (2005). Constitutive activation of phosphatidyl-inositide 3 kinase contributes to the survival of Hodgkin's lymphoma cells through a mechanism involving Akt kinase and mTOR. J Pathol, Vol.205, No.4, pp. 498-506, 0022-3417

Eberle, F.C.; Rodriguez-Canales, J.; Wei, L.; Hanson, J.C.; Killian, J.K.; Sun, H.W.; Adams, L.G.; Hewitt, S.M.; Wilson, W.H.; Pittaluga, S.; Meltzer, P.S.; Staudt, L.M.; EmmertBuck, M.R. \& Jaffe, E.S. (2011). Methylation profiling of mediastinal gray zone 
lymphoma reveals a distinctive signature with elements shared by classical Hodgkin's lymphoma and primary mediastinal large B-cell lymphoma. Haematologica, Vol.96, No.4, pp. 558-566, 1592-8721

Ekstrand, B.C.; Lucas, J.B.; Horwitz, S.M.; Fan, Z.; Breslin, S.; Hoppe, R.T.; Natkunam, Y.; Bartlett, N.L. \& Horning, S.J. (2003). Rituximab in lymphocyte-predominant Hodgkin disease: results of a phase 2 trial. Blood, Vol.101, No.11, pp. 4285-4289, 0006-4971

Emmerich, F.; Meiser, M.; Hummel, M.; Demel, G.; Foss, H.D.; Jundt, F.; Mathas, S.; Krappmann, D.; Scheidereit, C.; Stein, H. \& Dorken, B. (1999). Overexpression of I kappa B alpha without inhibition of NF-kappaB activity and mutations in the I kappa B alpha gene in Reed-Sternberg cells. Blood, Vol.94, No.9, pp. 3129-3134, 0006-4971

Emmerich, F.; Theurich, S.; Hummel, M.; Haeffker, A.; Vry, M.S.; Dohner, K.; Bommert, K.; Stein, H. \& Dorken, B. (2003). Inactivating I kappa B epsilon mutations in Hodgkin/Reed-Sternberg cells. J Pathol, Vol.201, No.3, pp. 413-420, 0022-3417

Engert, A.; Plutschow, A.; Eich, H.T.; Lohri, A.; Dorken, B.; Borchmann, P.; Berger, B.; Greil, R.; Willborn, K.C.; Wilhelm, M.; Debus, J.; Eble, M.J.; Sokler, M.; Ho, A.; Rank, A.; Ganser, A.; Trumper, L.; Bokemeyer, C.; Kirchner, H.; Schubert, J.; Kral, Z.; Fuchs, M.; Muller-Hermelink, H.K.; Muller, R.P. \& Diehl, V. (2010). Reduced treatment intensity in patients with early-stage Hodgkin's lymphoma. N Engl J Med, Vol.363, No.7, pp. 640-652, 1533-4406

Falini, B.; Bolognesi, A.; Flenghi, L.; Tazzari, P.L.; Broe, M.K.; Stein, H.; Durkop, H.; Aversa, F.; Corneli, P.; Pizzolo, G. \& et al. (1992). Response of refractory Hodgkin's disease to monoclonal anti-CD30 immunotoxin. Lancet, Vol.339, No.8803, pp. 1195-1196, 0140-6736

Falini, B.; Pileri, S.; Stein, H.; Dieneman, D.; Dallenbach, F.; Delsol, G.; Minelli, O.; Poggi, S.; Martelli, M.F.; Pallesen, G. \& et al. (1990). Variable expression of leucocyte-common (CD45) antigen in CD30 (Ki1)-positive anaplastic large-cell lymphoma: implications for the differential diagnosis between lymphoid and nonlymphoid malignancies. Hum Pathol, Vol.21, No.6, pp. 624-629, 0046-8177

Falini, B.; Stein, H.; Pileri, S.; Canino, S.; Farabbi, R.; Martelli, M.F.; Grignani, F.; Fagioli, M.; Minelli, O.; Ciani, C. \& et al. (1987). Expression of lymphoid-associated antigens on Hodgkin's and Reed-Sternberg cells of Hodgkin's disease. An immunocytochemical study on lymph node cytospins using monoclonal antibodies. Histopathology, Vol.11, No.12, pp. 1229-1242, 0309-0167

Famularo, G.; De Simone, C.; Tzantzoglou, S. \& Trinchieri, V. (1994). Apoptosis, antiapoptotic compounds and TNF-alpha release. Immunol Today, Vol.15, No.10, pp. 495-496, 0167-5699

Farrell, K. \& Jarrett, R.F. (2011). The molecular pathogenesis of Hodgkin lymphoma. Histopathology, Vol.58, No.1, pp. 15-25, 1365-2559

Filippa, D.A.; Ladanyi, M.; Wollner, N.; Straus, D.J.; O'Brien, J.P.; Portlock, C.; Gangi, M. \& Sun, M. (1996). CD30 (Ki-1)-positive malignant lymphomas: clinical, immunophenotypic, histologic, and genetic characteristics and differences with Hodgkin's disease. Blood, Vol.87, No.7, pp. 2905-2917, 0006-4971

Fischer, M.; Juremalm, M.; Olsson, N.; Backlin, C.; Sundstrom, C.; Nilsson, K.; Enblad, G. \& Nilsson, G. (2003). Expression of CCL5/RANTES by Hodgkin and Reed-Sternberg 
cells and its possible role in the recruitment of mast cells into lymphomatous tissue. Int J Cancer, Vol.107, No.2, pp. 197-201, 0020-7136

Fontenot, J.D.; Gavin, M.A. \& Rudensky, A.Y. (2003). Foxp3 programs the development and function of CD4+CD25+ regulatory T cells. Nat Immunol, Vol.4, No.4, pp. 330-336,

Formenti, S.C. \& Demaria, S. (2009). Systemic effects of local radiotherapy. Lancet Oncol, Vol.10, No.7, pp. 718-726, 1474-5488

Foss, H.D.; Reusch, R.; Demel, G.; Lenz, G.; Anagnostopoulos, I.; Hummel, M. \& Stein, H. (1999). Frequent expression of the B-cell-specific activator protein in ReedSternberg cells of classical Hodgkin's disease provides further evidence for its B-cell origin. Blood, Vol.94, No.9, pp. 3108-3113, 0006-4971

Foyil, K.V. \& Bartlett, N.L. (2010). Anti-CD30 Antibodies for Hodgkin lymphoma. Curr Hematol Malig Rep, Vol.5, No.3, pp. 140-147, 1558-822X

Friedberg, J.W. (2011). Hodgkin lymphoma: answers take time! Blood, Vol.117, No.20, pp. 5274-5276, 1528-0020

Frisan, T.; Sjoberg, J.; Dolcetti, R.; Boiocchi, M.; De Re, V.; Carbone, A.; Brautbar, C.; Battat, S.; Biberfeld, P.; Eckman, M. \& et al. (1995). Local suppression of Epstein-Barr virus (EBV)-specific cytotoxicity in biopsies of EBV-positive Hodgkin's disease. Blood, Vol.86, No.4, pp. 1493-1501, 0006-4971

Gallamini, A.; Hutchings, M.; Rigacci, L.; Specht, L.; Merli, F.; Hansen, M.; Patti, C.; Loft, A.; Di Raimondo, F.; D'Amore, F.; Biggi, A.; Vitolo, U.; Stelitano, C.; Sancetta, R.; Trentin, L.; Luminari, S.; Iannitto, E.; Viviani, S.; Pierri, I. \& Levis, A. (2007). Early interim 2-[18F]fluoro-2-deoxy-D-glucose positron emission tomography is prognostically superior to international prognostic score in advanced-stage Hodgkin's lymphoma: a report from a joint Italian-Danish study. J Clin Oncol, Vol.25, No.24, pp. 3746-3752, 1527-7755

Garcia, J.F.; Camacho, F.I.; Morente, M.; Fraga, M.; Montalban, C.; Alvaro, T.; Bellas, C.; Castano, A.; Diez, A.; Flores, T.; Martin, C.; Martinez, M.A.; Mazorra, F.; Menarguez, J.; Mestre, M.J.; Mollejo, M.; Saez, A.I.; Sanchez, L. \& Piris, M.A. (2003). Hodgkin and Reed-Sternberg cells harbor alterations in the major tumor suppressor pathways and cell-cycle checkpoints: analyses using tissue microarrays. Blood, Vol.101, No.2, pp. 681-689, 0006-4971

Garcia, J.F.; Villuendas, R.; Algara, P.; Saez, A.I.; Sanchez-Verde, L.; Martinez-Montero, J.C.; Martinez, P. \& Piris, M.A. (1999). Loss of p16 protein expression associated with methylation of the p16INK4A gene is a frequent finding in Hodgkin's disease. Lab Invest, Vol.79, No.12, pp. 1453-1459, 0023-6837

Gaulard, P.; Swerdlow, S.; Harris, S. \& al., e. (2008). Other iatrogenic immunodeficiencyassociated lymphoproliferative disorders. In: World Health Organization Classification of Tumours, Pathology and Genetics of Tumours of Haematopoietic and Lymphoid Tissues., Swerdlow SH C.E., Harris NL, et al. (eds) (eds),350-351. IARC Press Lyon

Gerdes, J.; Van Baarlen, J.; Pileri, S.; Schwarting, R.; Van Unnik, J.A. \& Stein, H. (1987). Tumor cell growth fraction in Hodgkin's disease. Am J Pathol, Vol.128, No.3, pp. 390-393, 0002-9440

Gonthier, M.; Llobera, R.; Arnaud, J. \& Rubin, B. (2004). Self-reactive T cell receptor-reactive CD8+ T cells inhibit T cell lymphoma growth in vivo. J Immunol, Vol.173, No.11, pp. 7062-7069, 0022-1767 
Goyal, R.K.; McEvoy, L. \& Wilson, D.B. (1996). Hodgkin disease after renal transplantation in childhood. J Pediatr Hematol Oncol, Vol.18, No.4, pp. 392-395, 1077-4114

Green, T.P.; Fennell, M.; Whittaker, R.; Curwen, J.; Jacobs, V.; Allen, J.; Logie, A.; Hargreaves, J.; Hickinson, D.M.; Wilkinson, R.W.; Elvin, P.; Boyer, B.; Carragher, N.; Ple, P.A.; Bermingham, A.; Holdgate, G.A.; Ward, W.H.; Hennequin, L.F.; Davies, B.R. \& Costello, G.F. (2009). Preclinical anticancer activity of the potent, oral Src inhibitor AZD0530. Mol Oncol, Vol.3, No.3, pp. 248-261, 1574-7891

Grogg, K.L.; Miller, R.F. \& Dogan, A. (2007). HIV infection and lymphoma. J Clin Pathol, Vol.60, No.12, pp. 1365-1372, 1472-4146

Gruss, H.J.; Brach, M.A.; Drexler, H.G.; Bonifer, R.; Mertelsmann, R.H. \& Herrmann, F. (1992). Expression of cytokine genes, cytokine receptor genes, and transcription factors in cultured Hodgkin and Reed-Sternberg cells. Cancer Res, Vol.52, No.12, pp. 3353-3360, 0008-5472

Guenova, M.; Rassidakis, G.Z.; Gorgoulis, V.G.; Angelopoulou, M.K.; Siakantaris, M.R.; Kanavaros, P.; Pangalis, G.A. \& Kittas, C. (1999). p16INK4A is regularly expressed in Hodgkin's disease: comparison with retinoblastoma, p53 and MDM2 protein status, and the presence of Epstein-Barr virus. Mod Pathol, Vol.12, No.11, pp. 10621071, 0893-3952

Hagemann, T.; Lawrence, T.; McNeish, I.; Charles, K.A.; Kulbe, H.; Thompson, R.G.; Robinson, S.C. \& Balkwill, F.R. (2008). "Re-educating" tumor-associated macrophages by targeting NF-kappaB. J Exp Med, Vol.205, No.6, pp. 1261-1268, 1540-9538

Hahne, M.; Renno, T.; Schroeter, M.; Irmler, M.; French, L.; Bornard, T.; MacDonald, H.R. \& Tschopp, J. (1996). Activated B cells express functional Fas ligand. Eur J Immunol, Vol.26, No.3, pp. 721-724, 0014-2980

Hanamoto, H.; Nakayama, T.; Miyazato, H.; Takegawa, S.; Hieshima, K.; Tatsumi, Y.; Kanamaru, A. \& Yoshie, O. (2004). Expression of CCL28 by Reed-Sternberg cells defines a major subtype of classical Hodgkin's disease with frequent infiltration of eosinophils and/or plasma cells. Am J Pathol, Vol.164, No.3, pp. 997-1006, 0002-9440

Haque, T.; Wilkie, G.M.; Jones, M.M.; Higgins, C.D.; Urquhart, G.; Wingate, P.; Burns, D.; McAulay, K.; Turner, M.; Bellamy, C.; Amlot, P.L.; Kelly, D.; MacGilchrist, A.; Gandhi, M.K.; Swerdlow, A.J.; Crawford, D.H. (2007). Allogeneic cytotoxic T cell therapy for EBV-positive posttransplantation lymphoproliferative disease: results of a phase 2 multicenter clinical trial. Blood, Vol. 110, No.4, pp 1123-31, 0006-4971

Harris, N.L.; Jaffe, E.S.; Diebold, J.; Flandrin, G.; Muller-Hermelink, H.K.; Vardiman, J.; Lister, T.A. \& Bloomfield, C.D. (2000). The World Health Organization classification of neoplastic diseases of the haematopoietic and lymphoid tissues: Report of the Clinical Advisory Committee Meeting, Airlie House, Virginia, November 1997. Histopathology, Vol.36, No.1, pp. 69-86, 0309-0167

Harris, N.L.; Jaffe, E.S.; Stein, H.; Banks, P.M.; Chan, J.K.; Cleary, M.L.; Delsol, G.; De WolfPeeters, C.; Falini, B.; Gatter, K.C. \& et al. (1994). A revised European-American classification of lymphoid neoplasms: a proposal from the International Lymphoma Study Group. Blood, Vol.84, No.5, pp. 1361-1392, 0006-4971

Hartmann, F.; Renner, C.; Jung, W.; da Costa, L.; Tembrink, S.; Held, G.; Sek, A.; Konig, J.; Bauer, S.; Kloft, M. \& Pfreundschuh, M. (2001). Anti-CD16/CD30 bispecific 
antibody treatment for Hodgkin's disease: role of infusion schedule and costimulation with cytokines. Clin Cancer Res, Vol.7, No.7, pp. 1873-1881, 1078-0432

Hartmann, F.; Renner, C.; Jung, W.; Deisting, C.; Juwana, M.; Eichentopf, B.; Kloft, M. \& Pfreundschuh, M. (1997). Treatment of refractory Hodgkin's disease with an antiCD16/CD30 bispecific antibody. Blood, Vol.89, No.6, pp. 2042-2047, 0006-4971

Hasenclever, D. \& Diehl, V. (1998). A prognostic score for advanced Hodgkin's disease. International Prognostic Factors Project on Advanced Hodgkin's Disease. N Engl J Med, Vol.339, No.21, pp. 1506-1514, 0028-4793

Haynes, N.M.; van der Most, R.G.; Lake, R.A. \& Smyth, M.J. (2008). Immunogenic anticancer chemotherapy as an emerging concept. Curr Opin Immunol, Vol.20, No.5, pp. 545-557, 0952-7915

Hertel, C.B.; Zhou, X.G.; Hamilton-Dutoit, S.J. \& Junker, S. (2002). Loss of B cell identity correlates with loss of B cell-specific transcription factors in Hodgkin/ReedSternberg cells of classical Hodgkin lymphoma. Oncogene, Vol.21, No.32, pp. 49084920, 0950-9232

Hinz, M.; Lemke, P.; Anagnostopoulos, I.; Hacker, C.; Krappmann, D.; Mathas, S.; Dorken, B.; Zenke, M.; Stein, H. \& Scheidereit, C. (2002). Nuclear factor kappaB-dependent gene expression profiling of Hodgkin's disease tumor cells, pathogenetic significance, and link to constitutive signal transducer and activator of transcription 5a activity. J Exp Med, Vol.196, No.5, pp. 605-617, 0022-1007

Hinz, M.; Loser, P.; Mathas, S.; Krappmann, D.; Dorken, B. \& Scheidereit, C. (2001). Constitutive NF-kappaB maintains high expression of a characteristic gene network, including CD40, CD86, and a set of antiapoptotic genes in Hodgkin/Reed-Sternberg cells. Blood, Vol.97, No.9, pp. 2798-2807, 0006-4971

Hiscox, S.; Barrett-Lee, P. \& Nicholson, R.I. (2011). Therapeutic targeting of tumor-stroma interactions. Expert Opin Ther Targets, Vol.15, No.5, pp. 609-621, 1744-7631

Hislop, A.D.; Annels, N.E.; Gudgeon, N.H.; Leese, A.M. \& Rickinson, A.B. (2002). Epitopespecific evolution of human CD8(+) T cell responses from primary to persistent phases of Epstein-Barr virus infection. J Exp Med, Vol.195, No.7, pp. 893-905, 00221007

Hnatkova, M.; Mocikova, H.; Trneny, M. \& Zivny, J. (2009). The biological environment of Hodgkin's lymphoma and the role of the chemokine CCL17/TARC. Prague Med Rep, Vol.110, No.1, pp. 35-41, 1214-6994

Hong, S.Y.; Yoon, W.H.; Park, J.H.; Kang, S.G.; Ahn, J.H. \& Lee, T.H. (2000). Involvement of two NF-kappa B binding elements in tumor necrosis factor alpha -, CD40-, and epstein-barr virus latent membrane protein 1-mediated induction of the cellular inhibitor of apoptosis protein 2 gene. J Biol Chem, Vol.275, No.24, pp. 18022-18028, 0021-9258

Hori, S.; Nomura, T. \& Sakaguchi, S. (2003). Control of regulatory T cell development by the transcription factor Foxp3. Science, Vol.299, No.5609, pp. 1057-1061, 0036-8075

Horie, R.; Watanabe, T.; Morishita, Y.; Ito, K.; Ishida, T.; Kanegae, Y.; Saito, I.; Higashihara, M.; Mori, S.; Kadin, M.E. \& Watanabe, T. (2002). Ligand-independent signaling by overexpressed CD30 drives NF-kappaB activation in Hodgkin-Reed-Sternberg cells. Oncogene, Vol.21, No.16, pp. 2493-2503, 0950-9232 
Hsu, S.M.; Krupen, K. \& Lachman, L.B. (1989). Heterogeneity of interleukin 1 production in cultured Reed-Sternberg cell lines HDLM-1, HDLM-1d, and KM-H2. Am J Pathol, Vol.135, No.1, pp. 33-38, 0002-9440

Hutchings, M.; Mikhaeel, N.G.; Fields, P.A.; Nunan, T. \& Timothy, A.R. (2005). Prognostic value of interim FDG-PET after two or three cycles of chemotherapy in Hodgkin lymphoma. Ann Oncol, Vol.16, No.7, pp. 1160-1168, 0923-7534

Ichim, C.V. (2005). Revisiting immunosurveillance and immunostimulation: Implications for cancer immunotherapy. J Transl Med, Vol.3, No.1, pp. 8, 1479-5876, 1479-5876

Ikeda, H.; Old, L.J. \& Schreiber, R.D. (2002). The roles of IFN gamma in protection against tumor development and cancer immunoediting. Cytokine Growth Factor Rev, Vol.13, No.2, pp. 95-109, 1359-6101

Inoki, K.; Li, Y.; Zhu, T.; Wu, J. \& Guan, K.L. (2002). TSC2 is phosphorylated and inhibited by Akt and suppresses mTOR signalling. Nat Cell Biol, Vol.4, No.9, pp. 648-657, $1465-7392$

Inoue, J.; Ishida, T.; Tsukamoto, N.; Kobayashi, N.; Naito, A.; Azuma, S. \& Yamamoto, T. (2000). Tumor necrosis factor receptor-associated factor (TRAF) family: adapter proteins that mediate cytokine signaling. Exp Cell Res, Vol.254, No.1, pp. 14-24, 0014-4827

Izban, K.F.; Ergin, M.; Huang, Q.; Qin, J.Z.; Martinez, R.L.; Schnitzer, B.; Ni, H.; Nickoloff, B.J. \& Alkan, S. (2001). Characterization of NF-kappaB expression in Hodgkin's disease: inhibition of constitutively expressed NF-kappaB results in spontaneous caspase-independent apoptosis in Hodgkin and Reed-Sternberg cells. Mod Pathol, Vol.14, No.4, pp. 297-310, 0893-3952

Jarrett, R.F. (2002). Viruses and Hodgkin's lymphoma. Ann Oncol, Vol.13 Suppl 1, pp. 23-29, 0923-7534

Jarrett, R.F. (2006). Viruses and lymphoma/leukaemia. J Pathol, Vol.208, No.2, pp. 176-186, 0022-3417

Joos, S.; Granzow, M.; Holtgreve-Grez, H.; Siebert, R.; Harder, L.; Martin-Subero, J.I.; Wolf, J.; Adamowicz, M.; Barth, T.F.; Lichter, P. \& Jauch, A. (2003). Hodgkin's lymphoma cell lines are characterized by frequent aberrations on chromosomes $2 p$ and $9 p$ including REL and JAK2. Int J Cancer, Vol.103, No.4, pp. 489-495, 0020-7136

Joos, S.; Menz, C.K.; Wrobel, G.; Siebert, R.; Gesk, S.; Ohl, S.; Mechtersheimer, G.; Trumper, L.; Moller, P.; Lichter, P. \& Barth, T.F. (2002). Classical Hodgkin lymphoma is characterized by recurrent copy number gains of the short arm of chromosome 2 . Blood, Vol.99, No.4, pp. 1381-1387, 0006-4971

Jourdan, M.; De Vos, J.; Mechti, N. \& Klein, B. (2000). Regulation of Bcl-2-family proteins in myeloma cells by three myeloma survival factors: interleukin-6, interferon-alpha and insulin-like growth factor 1. Cell Death Differ, Vol.7, No.12, pp. 1244-1252, 13509047

Jungnickel, B.; Staratschek-Jox, A.; Brauninger, A.; Spieker, T.; Wolf, J.; Diehl, V.; Hansmann, M.L.; Rajewsky, K. \& Kuppers, R. (2000). Clonal deleterious mutations in the IkappaBalpha gene in the malignant cells in Hodgkin's lymphoma. J Exp Med, Vol.191, No.2, pp. 395-402, 0022-1007

Juszczynski, P.; Ouyang, J.; Monti, S.; Rodig, S.J.; Takeyama, K.; Abramson, J.; Chen, W.; Kutok, J.L.; Rabinovich, G.A. \& Shipp, M.A. (2007). The AP1-dependent secretion 
of galectin- 1 by Reed Sternberg cells fosters immune privilege in classical Hodgkin lymphoma. Proc Natl Acad Sci U S A, Vol.104, No.32, pp. 13134-13139, 0027-8424

Kamper, P.; Bendix, K.; Hamilton-Dutoit, S.; Honore, B.; Nyengaard, J.R. \& d'Amore, F. (2011). Tumor-infiltrating macrophages correlate with adverse prognosis and Epstein-Barr virus status in classical Hodgkin's lymphoma. Haematologica, Vol.96, No.2, pp. 269-276, 1592-8721

Kanavaros, P.; Stefanaki, K.; Vlachonikolis, J.; Eliopoulos, G.; Kakolyris, S.; Rontogianni, D.; Gorgoulis, V. \& Georgoulias, V. (2000). Expression of p53, p21/waf1, bcl-2, bax, Rb and Ki67 proteins in Hodgkin's lymphomas. Histol Histopathol, Vol.15, No.2, pp. 445-453, 0213-3911

Kanavaros, P.; Vlychou, M.; Stefanaki, K.; Rontogianni, D.; Gaulard, P.; Pantelidaki, E.; Zois, M.; Darivianaki, K.; Georgoulias, V.; Boulland, M.L.; Gorgoulis, V. \& Kittas, C. (1999). Cytotoxic protein expression in non-Hodgkin's lymphomas and Hodgkin's disease. Anticancer Res, Vol.19, No.2A, pp. 1209-1216, 0250-7005

Kanzler, H.; Kuppers, R.; Hansmann, M.L. \& Rajewsky, K. (1996). Hodgkin and ReedSternberg cells in Hodgkin's disease represent the outgrowth of a dominant tumor clone derived from (crippled) germinal center B cells. J Exp Med, Vol.184, No.4, pp. 1495-1505, 0022-1007

Kapatai, G. \& Murray, P. (2007). Contribution of the Epstein Barr virus to the molecular pathogenesis of Hodgkin lymphoma. J Clin Pathol, Vol.60, No.12, pp. 1342-1349, $1472-4146$

Karin, M. \& Greten, F.R. (2005). NF-kappaB: linking inflammation and immunity to cancer development and progression. Nat Rev Immunol, Vol.5, No.10, pp. 749-759, 14741733

Karube, K.; Ohshima, K.; Tsuchiya, T.; Yamaguchi, T.; Kawano, R.; Suzumiya, J.; Utsunomiya, A.; Harada, M. \& Kikuchi, M. (2004). Expression of FoxP3, a key molecule in CD4CD25 regulatory $\mathrm{T}$ cells, in adult T-cell leukaemia/lymphoma cells. Br J Haematol, Vol.126, No.1, pp. 81-84, 0007-1048

Kasamon, Y.L.; Ambinder, R.F. (2008). Immunotherapies for Hodgkin's lymphoma. Crit Rev Oncol Hematol, Vol. 66, No.2, pp 135-144, 1040-8428

Kater, A.P.; Evers, L.M.; Remmerswaal, E.B.; Jaspers, A.; Oosterwijk, M.F.; van Lier, R.A.; van Oers, M.H. \& Eldering, E. (2004). CD40 stimulation of B-cell chronic lymphocytic leukaemia cells enhances the anti-apoptotic profile, but also Bid expression and cells remain susceptible to autologous cytotoxic T-lymphocyte attack. Br J Haematol, Vol.127, No.4, pp. 404-415, 0007-1048

Kato, M.; Sanada, M.; Kato, I.; Sato, Y.; Takita, J.; Takeuchi, K.; Niwa, A.; Chen, Y.; Nakazaki, K.; Nomoto, J.; Asakura, Y.; Muto, S.; Tamura, A.; Iio, M.; Akatsuka, Y.; Hayashi, Y.; Mori, H.; Igarashi, T.; Kurokawa, M.; Chiba, S.; Mori, S.; Ishikawa, Y.; Okamoto, K.; Tobinai, K.; Nakagama, H.; Nakahata, T.; Yoshino, T.; Kobayashi, Y. \& Ogawa, S. (2009). Frequent inactivation of A20 in B-cell lymphomas. Nature, Vol.459, No.7247, pp. 712-716, 1476-4687

Kennedy, G.; Komano, J. \& Sugden, B. (2003). Epstein-Barr virus provides a survival factor to Burkitt's lymphomas. Proc Natl Acad Sci U S A, Vol.100, No.24, pp. 14269-14274, 0027-8424 
Khan, G. (2006). Epstein-Barr virus, cytokines, and inflammation: a cocktail for the pathogenesis of Hodgkin's lymphoma? Exp Hematol, Vol.34, No.4, pp. 399-406, 0301-472X

Kilger, E.; Kieser, A.; Baumann, M. \& Hammerschmidt, W. (1998). Epstein-Barr virusmediated B-cell proliferation is dependent upon latent membrane protein 1, which simulates an activated CD40 receptor. Embo J, Vol.17, No.6, pp. 1700-1709, 02614189

Kim, T.H.; Kim, H.I.; Soung, Y.H.; Shaw, L.A. \& Chung, J. (2009). Integrin (alpha6beta4) signals through Src to increase expression of S100A4, a metastasis-promoting factor: implications for cancer cell invasion. Mol Cancer Res, Vol.7, No.10, pp. 1605$1612,1557-3125$

Klimm, B.; Schnell, R.; Diehl, V. \& Engert, A. (2005). Current treatment and immunotherapy of Hodgkin's lymphoma. Haematologica, Vol.90, No.12, pp. 1680-1692, 1592-8721

Knight, J.S.; Tsodikov, A.; Cibrik, D.M.; Ross, C.W.; Kaminski, M.S. \& Blayney, D.W. (2009). Lymphoma after solid organ transplantation: risk, response to therapy, and survival at a transplantation center. J Clin Oncol, Vol.27, No.20, pp. 3354-3362, 15277755

Kolar, Z.; Flavell, J.R.; Ehrmann, J., Jr.; Rihakova, P.; Macak, J.; Lowe, D.; Crocker, J.; Vojtesek, B.; Young, L.S. \& Murray, P.G. (2000). Apoptosis of malignant cells in Hodgkin's disease is related to expression of the cdk inhibitor p27KIP1. J Pathol, Vol.190, No.5, pp. 604-612, 0022-3417

Korkolopoulou, P.; Cordell, J.; Jones, M.; Kaklamanis, L.; Tsenga, A.; Gatter, K.C. \& Mason, D.Y. (1994). The expression of the B-cell marker mb-1 (CD79a) in Hodgkin's disease. Histopathology, Vol.24, No.6, pp. 511-515, 0309-0167

Kreitman, R.J.; Wilson, W.H.; White, J.D.; Stetler-Stevenson, M.; Jaffe, E.S.; Giardina, S.; Waldmann, T.A. \& Pastan, I. (2000). Phase I trial of recombinant immunotoxin antiTac(Fv)-PE38 (LMB-2) in patients with hematologic malignancies. J Clin Oncol, Vol.18, No.8, pp. 1622-1636, 0732-183X

Krishnamurthy, S.; Hassan, A.; Frater, J.L.; Paessler, M.E. \& Kreisel, F.H. (2010). Pathologic and clinical features of Hodgkin lymphoma--like posttransplant lymphoproliferative disease. Int J Surg Pathol, Vol.18, No.4, pp. 278-285, 1940-2465

Kube, D.; Holtick, U.; Vockerodt, M.; Ahmadi, T.; Haier, B.; Behrmann, I.; Heinrich, P.C.; Diehl, V. \& Tesch, H. (2001). STAT3 is constitutively activated in Hodgkin cell lines. Blood, Vol.98, No.3, pp. 762-770, 0006-4971

Kupper, M.; Joos, S.; von Bonin, F.; Daus, H.; Pfreundschuh, M.; Lichter, P. \& Trumper, L. (2001). MDM2 gene amplification and lack of p53 point mutations in Hodgkin and Reed-Sternberg cells: results from single-cell polymerase chain reaction and molecular cytogenetic studies. Br J Haematol, Vol.112, No.3, pp. 768-775, 0007-1048

Kuppers, R. (2002). Molecular biology of Hodgkin's lymphoma. Adv Cancer Res, Vol.84, pp. 277-312, 0065-230X

Kuppers, R.; Hajadi, M.; Plank, L.; Rajewsky, K. \& Hansmann, M.L. (1996). Molecular Ig gene analysis reveals that monocytoid $\mathrm{B}$ cell lymphoma is a malignancy of mature $\mathrm{B}$ cells carrying somatically mutated $\mathrm{V}$ region genes and suggests that rearrangement of the kappa-deleting element (resulting in deletion of the Ig kappa enhancers) abolishes somatic hypermutation in the human. Eur J Immunol, Vol.26, No.8, pp. 1794-1800, 0014-2980 
Kuppers, R.; Klein, U.; Schwering, I.; Distler, V.; Brauninger, A.; Cattoretti, G.; Tu, Y.; Stolovitzky, G.A.; Califano, A.; Hansmann, M.L. \& Dalla-Favera, R. (2003). Identification of Hodgkin and Reed-Sternberg cell-specific genes by gene expression profiling. J Clin Invest, Vol.111, No.4, pp. 529-537, 0021-9738

Kuppers, R.; Rajewsky, K.; Zhao, M.; Simons, G.; Laumann, R.; Fischer, R. \& Hansmann, M.L. (1994). Hodgkin disease: Hodgkin and Reed-Sternberg cells picked from histological sections show clonal immunoglobulin gene rearrangements and appear to be derived from B cells at various stages of development. Proc Natl Acad Sci U S A, Vol.91, No.23, pp. 10962-10966, 0027-8424

Kuppers, R.; Sousa, A.B.; Baur, A.S.; Strickler, J.G.; Rajewsky, K. \& Hansmann, M.L. (2001). Common germinal-center B-cell origin of the malignant cells in two composite lymphomas, involving classical Hodgkin's disease and either follicular lymphoma or B-CLL. Mol Med, Vol.7, No.5, pp. 285-292, 1076-1551

Lake, A.; Shield, L.A.; Cordano, P.; Chui, D.T.; Osborne, J.; Crae, S.; Wilson, K.S.; Tosi, S.; Knight, S.J.; Gesk, S.; Siebert, R.; Hay, R.T. \& Jarrett, R.F. (2009). Mutations of NFKBIA, encoding IkappaB alpha, are a recurrent finding in classical Hodgkin lymphoma but are not a unifying feature of non-EBV-associated cases. Int J Cancer, Vol.125, No.6, pp. 1334-1342, 1097-0215

Lam, N. \& Sugden, B. (2003). CD40 and its viral mimic, LMP1: similar means to different ends. Cell Signal, Vol.15, No.1, pp. 9-16, 0898-6568

Lauritzen, A.F.; Moller, P.H.; Nedergaard, T.; Guldberg, P.; Hou-Jensen, K. \& Ralfkiaer, E. (1999). Apoptosis-related genes and proteins in Hodgkin's disease. Apmis, Vol.107, No.7, pp. 636-644, 0903-4641

Lee, H.H.; Dadgostar, H.; Cheng, Q.; Shu, J. \& Cheng, G. (1999). NF-kappaB-mediated upregulation of $\mathrm{Bcl}-\mathrm{x}$ and $\mathrm{Bfl}-1 / \mathrm{A} 1$ is required for CD40 survival signaling in $\mathrm{B}$ lymphocytes. Proc Natl Acad Sci U S A, Vol.96, No.16, pp. 9136-9141, 0027-8424

Leoncini, L.; Spina, D.; Megha, T.; Gallorini, M.; Tosi, P.; Hummel, M.; Stein, H.; Pileri, S.; Kraft, R.; Laissue, J.A. \& Cottier, H. (1997). Cell kinetics, morphology, and molecular IgVH gene rearrangements in Hodgkin's disease. Leuk Lymphoma, Vol.26, No.3-4, pp. 307-316, 1042-8194

Lucas, K.G.; Salzman, D.; García, A.; Sun, Q. (2004). Adoptive immunotherapy with allogeneic Epstein-Barr virus (EBV)-specific cytotoxic T-lymphocytes for recurrent EBV-positive Hodgkin disease. Cancer, Vol. 100, No 9, pp 1892-901, 0008-543X

Maggioncalda, A.; Malik, N.; Shenoy, P.; Smith, M.; Sinha, R. \& Flowers, C.R. (2011). Clinical, molecular, and environmental risk factors for hodgkin lymphoma. Adv Hematol, Vol.2011, pp. 736261, 1687-9112

Maier, S.K. \& Hammond, J.M. (2006). Role of lenalidomide in the treatment of multiple myeloma and myelodysplastic syndrome. Ann Pharmacother, Vol.40, No.2, pp. 286289, 1060-0280

Malumbres, M. \& Barbacid, M. (2001). To cycle or not to cycle: a critical decision in cancer. Nat Rev Cancer, Vol.1, No.3, pp. 222-231, 1474-175X

Marafioti, T.; Hummel, M.; Foss, H.D.; Laumen, H.; Korbjuhn, P.; Anagnostopoulos, I.; Lammert, H.; Demel, G.; Theil, J.; Wirth, T. \& Stein, H. (2000). Hodgkin and reedsternberg cells represent an expansion of a single clone originating from a germinal center B-cell with functional immunoglobulin gene rearrangements but defective immunoglobulin transcription. Blood, Vol.95, No.4, pp. 1443-1450, 0006-4971 
Marshall, N.A.; Christie, L.E.; Munro, L.R.; Culligan, D.J.; Johnston, P.W.; Barker, R.N. \& Vickers, M.A. (2004). Immunosuppressive regulatory $T$ cells are abundant in the reactive lymphocytes of Hodgkin lymphoma. Blood, Vol.103, No.5, pp. 1755-1762, 0006-4971

Martin-Subero, J.I.; Gesk, S.; Harder, L.; Sonoki, T.; Tucker, P.W.; Schlegelberger, B.; Grote, W.; Novo, F.J.; Calasanz, M.J.; Hansmann, M.L.; Dyer, M.J. \& Siebert, R. (2002). Recurrent involvement of the REL and BCL11A loci in classical Hodgkin lymphoma. Blood, Vol.99, No.4, pp. 1474-1477, 0006-4971

Mason, D.Y.; Banks, P.M.; Chan, J.; Cleary, M.L.; Delsol, G.; de Wolf Peeters, C.; Falini, B.; Gatter, K.; Grogan, T.M.; Harris, N.L. \& et al. (1994). Nodular lymphocyte predominance Hodgkin's disease. A distinct clinicopathological entity. Am J Surg Pathol, Vol.18, No.5, pp. 526-530, 0147-5185

Mathas, S.; Hinz, M.; Anagnostopoulos, I.; Krappmann, D.; Lietz, A.; Jundt, F.; Bommert, K.; Mechta-Grigoriou, F.; Stein, H.; Dorken, B. \& Scheidereit, C. (2002). Aberrantly expressed c-Jun and JunB are a hallmark of Hodgkin lymphoma cells, stimulate proliferation and synergize with NF-kappa B. Embo J, Vol.21, No.15, pp. 4104-4113, 0261-4189

Mathas, S.; Janz, M.; Hummel, F.; Hummel, M.; Wollert-Wulf, B.; Lusatis, S.; Anagnostopoulos, I.; Lietz, A.; Sigvardsson, M.; Jundt, F.; Johrens, K.; Bommert, K.; Stein, H. \& Dorken, B. (2006). Intrinsic inhibition of transcription factor E2A by HLH proteins ABF-1 and Id2 mediates reprogramming of neoplastic B cells in Hodgkin lymphoma. Nat Immunol, Vol.7, No.2, pp. 207-215, 1529-2908

Medema, J.P.; de Jong, J.; Peltenburg, L.T.; Verdegaal, E.M.; Gorter, A.; Bres, S.A.; Franken, K.L.; Hahne, M.; Albar, J.P.; Melief, C.J. \& Offringa, R. (2001). Blockade of the granzyme $\mathrm{B} /$ perforin pathway through overexpression of the serine protease inhibitor PI-9/SPI-6 constitutes a mechanism for immune escape by tumors. Proc Natl Acad Sci U S A, Vol.98, No.20, pp. 11515-11520, 0027-8424

Messineo, C.; Jamerson, M.H.; Hunter, E.; Braziel, R.; Bagg, A.; Irving, S.G. \& Cossman, J. (1998). Gene expression by single Reed-Sternberg cells: pathways of apoptosis and activation. Blood, Vol.91, No.7, pp. 2443-2451, 0006-4971

Metkar, S.S.; Manna, P.P.; Anand, M.; Naresh, K.N.; Advani, S.H. \& Nadkarni, J.J. (2001). CD40 Ligand--an anti-apoptotic molecule in Hodgkin's disease. Cancer Biother Radiopharm, Vol.16, No.1, pp. 85-92, 1084-9785

Montalban, C.; Abraira, V.; Morente, M.; Acevedo, A.; Aguilera, B.; Bellas, C.; Fraga, M.; Del Moral, R.G.; Menarguez, J.; Oliva, H.; Sanchez-Beato, M. \& Piris, M.A. (2000). Epstein-Barr virus-latent membrane protein 1 expression has a favorable influence in the outcome of patients with Hodgkin's Disease treated with chemotherapy. Leuk Lymphoma, Vol.39, No.5-6, pp. 563-572, 1042-8194

Montalban, C.; Garcia, J.F.; Abraira, V.; Gonzalez-Camacho, L.; Morente, M.M.; Bello, J.L.; Conde, E.; Cruz, M.A.; Garcia-Sanz, R.; Garcia-Larana, J.; Grande, C.; Llanos, M.; Martinez, R.; Flores, E.; Mendez, M.; Ponderos, C.; Rayon, C.; Sanchez-Godoy, P.; Zamora, J. \& Piris, M.A. (2004). Influence of biologic markers on the outcome of Hodgkin's lymphoma: a study by the Spanish Hodgkin's Lymphoma Study Group. J Clin Oncol, Vol.22, No.9, pp. 1664-1673, 0732-183X 
Montesinos-Rongen, M.; Roers, A.; Kuppers, R.; Rajewsky, K. \& Hansmann, M.L. (1999). Mutation of the p53 gene is not a typical feature of Hodgkin and Reed-Sternberg cells in Hodgkin's disease. Blood, Vol.94, No.5, pp. 1755-1760, 0006-4971

Morente, M.M.; Piris, M.A.; Abraira, V.; Acevedo, A.; Aguilera, B.; Bellas, C.; Fraga, M.; Garcia-Del-Moral, R.; Gomez-Marcos, F.; Menarguez, J.; Oliva, H.; Sanchez-Beato, M. \& Montalban, C. (1997). Adverse clinical outcome in Hodgkin's disease is associated with loss of retinoblastoma protein expression, high Ki67 proliferation index, and absence of Epstein-Barr virus-latent membrane protein 1 expression. Blood, Vol.90, No.6, pp. 2429-2436

Muschen, M.; Kuppers, R.; Spieker, T.; Brauninger, A.; Rajewsky, K. \& Hansmann, M.L. (2001). Molecular single-cell analysis of Hodgkin- and Reed-Sternberg cells harboring unmutated immunoglobulin variable region genes. Lab Invest, Vol.81, No.3, pp. 289-295, 0023-6837

Muschen, M.; Rajewsky, K.; Brauninger, A.; Baur, A.S.; Oudejans, J.J.; Roers, A.; Hansmann, M.L. \& Kuppers, R. (2000). Rare occurrence of classical Hodgkin's disease as a T cell lymphoma. J Exp Med, Vol.191, No.2, pp. 387-394, 0022-1007

Newcom, S.R.; Kadin, M.E.; Ansari, A.A. \& Diehl, V. (1988). L-428 nodular sclerosing Hodgkin's cell secretes a unique transforming growth factor-beta active at physiologic pH. J Clin Invest, Vol.82, No.6, pp. 1915-1921, 0021-9738

Ng, A.K.; Bernardo, M.V.; Weller, E.; Backstrand, K.; Silver, B.; Marcus, K.C.; Tarbell, N.J.; Stevenson, M.A.; Friedberg, J.W. \& Mauch, P.M. (2002). Second malignancy after Hodgkin disease treated with radiation therapy with or without chemotherapy: long-term risks and risk factors. Blood, Vol.100, No.6, pp. 1989-1996, 0006-4971

Nie, L.; Xu, M.; Vladimirova, A. \& Sun, X.H. (2003). Notch-induced E2A ubiquitination and degradation are controlled by MAP kinase activities. Embo J, Vol.22, No.21, pp. 5780-5792, 0261-4189

Niens, M.; Visser, L.; Nolte, I.M.; van der Steege, G.; Diepstra, A.; Cordano, P.; Jarrett, R.F.; Te Meerman, G.J.; Poppema, S. \& van den Berg, A. (2008). Serum chemokine levels in Hodgkin lymphoma patients: highly increased levels of CCL17 and CCL22. $\mathrm{Br} \mathrm{J}$ Haematol, Vol.140, No.5, pp. 527-536, 1365-2141

Nogova, L.; Reineke, T.; Brillant, C.; Sieniawski, M.; Rudiger, T.; Josting, A.; Bredenfeld, H.; Skripnitchenko, R.; Muller, R.P.; Muller-Hermelink, H.K.; Diehl, V. \& Engert, A. (2008). Lymphocyte-predominant and classical Hodgkin's lymphoma: a comprehensive analysis from the German Hodgkin Study Group. J Clin Oncol, Vol.26, No.3, pp. 434-439, 1527-7755

Obeid, M.; Panaretakis, T.; Joza, N.; Tufi, R.; Tesniere, A.; van Endert, P.; Zitvogel, L. \& Kroemer, G. (2007a). Calreticulin exposure is required for the immunogenicity of gamma-irradiation and UVC light-induced apoptosis. Cell Death Differ, Vol.14, No.10, pp. 1848-1850, 1350-9047

Obeid, M.; Tesniere, A.; Ghiringhelli, F.; Fimia, G.M.; Apetoh, L.; Perfettini, J.L.; Castedo, M.; Mignot, G.; Panaretakis, T.; Casares, N.; Metivier, D.; Larochette, N.; van Endert, P.; Ciccosanti, F.; Piacentini, M.; Zitvogel, L. \& Kroemer, G. (2007b). Calreticulin exposure dictates the immunogenicity of cancer cell death. Nat Med, Vol.13, No.1, pp. 54-61, 1078-8956

Ohshima, K.; Haraoka, S.; Fujiki, T.; Yoshioka, S.; Suzumiya, J.; Kanda, M. \& Kikuchi, M. (1999). Expressions of cyclin E, A, and B1 in Hodgkin and Reed-Sternberg cells: not 
suppressed by cyclin-dependent kinase inhibitor p21 expression. Pathol Int, Vol.49, No.6, pp. 506-512, 1320-5463

Ohshima, K.; Suzumiya, J.; Akamatu, M.; Takeshita, M. \& Kikuchi, M. (1995). Human and viral interleukin-10 in Hodgkin's disease, and its influence on CD4+ and CD8+ T lymphocytes. Int J Cancer, Vol.62, No.1, pp. 5-10

Okeley, N.M.; Miyamoto, J.B.; Zhang, X.; Sanderson, R.J.; Benjamin, D.R.; Sievers, E.L.; Senter, P.D. \& Alley, S.C. (2010). Intracellular activation of SGN-35, a potent antiCD30 antibody-drug conjugate. Clin Cancer Res, Vol.16, No.3, pp. 888-897, 10780432

Oudejans, J.J.; Jiwa, N.M.; Kummer, J.A.; Ossenkoppele, G.J.; van Heerde, P.; Baars, J.W.; Kluin, P.M.; Kluin-Nelemans, J.C.; van Diest, P.J.; Middeldorp, J.M. \& Meijer, C.J. (1997). Activated cytotoxic T cells as prognostic marker in Hodgkin's disease. Blood, Vol.89, No.4, pp. 1376-1382, 0006-4971

Pages, F.; Galon, J.; Dieu-Nosjean, M.C.; Tartour, E.; Sautes-Fridman, C. \& Fridman, W.H. (2010). Immune infiltration in human tumors: a prognostic factor that should not be ignored. Oncogene, Vol.29, No.8, pp. 1093-1102, 1476-5594

Parsons, J.T.; Slack-Davis, J.; Tilghman, R. \& Roberts, W.G. (2008). Focal adhesion kinase: targeting adhesion signaling pathways for therapeutic intervention. Clin Cancer Res, Vol.14, No.3, pp. 627-632, 1078-0432 (

Peh, S.C.; Kim, L.H. \& Poppema, S. (2001). TARC, a CC chemokine, is frequently expressed in classic Hodgkin's lymphoma but not in NLP Hodgkin's lymphoma, T-cell-rich Bcell lymphoma, and most cases of anaplastic large cell lymphoma. Am J Surg Pathol, Vol.25, No.7, pp. 925-929, 0147-5185

Peipp, M. \& Valerius, T. (2002). Bispecific antibodies targeting cancer cells. Biochem Soc Trans, Vol.30, No.4, pp. 507-511, 0300-5127

Pham, P.T.; Wilkinson, A.H.; Gritsch, H.A.; Pham, P.C.; Miller, J.M.; Lassman, C.R. \& Danovitch, G.M. (2002). Monotherapy with the anti-CD20 monoclonal antibody rituximab in a kidney transplant recipient with posttransplant lymphoproliferative disease. Transplant Proc, Vol.34, No.4, pp. 1178-1181, 0041-1345

Piccaluga, P.P.; Agostinelli, C.; Gazzola, A.; Tripodo, C.; Bacci, F.; Sabattini, E.; Sista, M.T.; Mannu, C.; Sapienza, M.R.; Rossi, M.; Laginestra, M.A.; Sagramoso-Sacchetti, C.A.; Righi, S. \& Pileri, S.A. (2011). Pathobiology of hodgkin lymphoma. Adv Hematol, Vol.2011, pp. 920898, 1687-9112

Pileri, S.; Sabattini, E.; Tazzari, P.L.; Gherlinzoni, F.; Zucchini, L.; Bigerna, B.; Leoncini, L.; Rosso, R.; Stein, H. \& Falini, B. (1991). Hodgkin's disease: update of findings. Haematologica, Vol.76, No.3, pp. 175-182, 0390-6078

Pileri, S.A.; Poggi, S.; Sabattini, E.; De Vivo, A.; Falini, B. \& Stein, H. (1995). Is Hodgkin's disease a unique entity? Leuk Lymphoma, Vol.15 Suppl 1, pp. 3-6, 1042-8194

Poppema, S.; Potters, M.; Emmens, R.; Visser, L. \& van den Berg, A. (1999). Immune reactions in classical Hodgkin's lymphoma. Semin Hematol, Vol.36, No.3, pp. 253259, 0037-1963

Poppema, S.; Potters, M.; Visser, L. \& van den Berg, A.M. (1998). Immune escape mechanisms in Hodgkin's disease. Ann Oncol, Vol.9, No.Suppl 5, pp. S21-24, 09237534

Poppema, S. \& Visser, L. (1994). Absence of HLA class I expression by Reed-Sternberg cells. Am J Pathol, Vol.145, No.1, pp. 37-41, 0002-9440 
Portis, T.; Dyck, P. \& Longnecker, R. (2003). Epstein-Barr Virus (EBV) LMP2A induces alterations in gene transcription similar to those observed in Reed-Sternberg cells of Hodgkin lymphoma. Blood, Vol.102, No.12, pp. 4166-4178, 0006-4971

Powles, T. \& Bower, M. (2000). HIV-associated Hodgkin's disease. Int J STD AIDS, Vol.11, No.8, pp. 492-494.

Powles, T.; Robinson, D.; Stebbing, J.; Shamash, J.; Nelson, M.; Gazzard, B.; Mandelia, S.; Moller, H. \& Bower, M. (2009). Highly active antiretroviral therapy and the incidence of non-AIDS-defining cancers in people with HIV infection. J Clin Oncol, Vol.27, No.6, pp. 884-890, 1527-7755

Prehn, R.T. (1972). The immune reaction as a stimulator of tumor growth. Science, Vol.176, No.31, pp. 170-171, 0036-8075

Puthier, D.; Derenne, S.; Barille, S.; Moreau, P.; Harousseau, J.L.; Bataille, R. \& Amiot, M. (1999). Mcl-1 and Bcl-xL are co-regulated by IL-6 in human myeloma cells. Br J Haematol, Vol.107, No.2, pp. 392-395, 0007-1048

Quezada, S.A.; Simpson, T.R.; Peggs, K.S.; Merghoub, T.; Vider, J.; Fan, X.; Blasberg, R.; Yagita, H.; Muranski, P.; Antony, P.A.; Restifo, N.P. \& Allison, J.P. (2010). Tumorreactive CD4(+) T cells develop cytotoxic activity and eradicate large established melanoma after transfer into lymphopenic hosts. J Exp Med, Vol.207, No.3, pp. 637650, 1540-9538

Raphael, M.; Said, J.; Borish, B. \& al., e. (2008). Lymphomas associated with HIV infection. In: World Health Organization Classification of Tumours, Pathology and Genetics of Tumours of Haematopoietic and Lymphoid Tissues. , Swerdlow SH C.E., Harris NL, et al. (eds) (eds), 340-342. IARC Press Lyon

Rassidakis, G.Z.; Medeiros, L.J.; McDonnell, T.J.; Viviani, S.; Bonfante, V.; Nadali, G.; Vassilakopoulos, T.P.; Giardini, R.; Chilosi, M.; Kittas, C.; Gianni, A.M.; Bonadonna, G.; Pizzolo, G.; Pangalis, G.A.; Cabanillas, F. \& Sarris, A.H. (2002a). BAX expression in Hodgkin and Reed-Sternberg cells of Hodgkin's disease: correlation with clinical outcome. Clin Cancer Res, Vol.8, No.2, pp. 488-493, 10780432

Rassidakis, G.Z.; Medeiros, L.J.; Vassilakopoulos, T.P.; Viviani, S.; Bonfante, V.; Nadali, G.; Herling, M.; Angelopoulou, M.K.; Giardini, R.; Chilosi, M.; Kittas, C.; McDonnell, T.J.; Bonadonna, G.; Gianni, A.M.; Pizzolo, G.; Pangalis, G.A.; Cabanillas, F. \& Sarris, A.H. (2002b). BCL-2 expression in Hodgkin and Reed-Sternberg cells of classical Hodgkin disease predicts a poorer prognosis in patients treated with ABVD or equivalent regimens. Blood, Vol.100, No.12, pp. 3935-3941, 0006-4971

Rathore, B. \& Kadin, M.E. (2010). Hodgkin's lymphoma therapy: past, present, and future. Expert Opin Pharmacother, Vol.11, No.17, pp. 2891-2906, 1744-7666

Rautert, R.; Schinkothe, T.; Franklin, J.; Weihrauch, M.; Boll, B.; Pogge, E.; Bredenfeld, H.; Engert, A.; Diehl, V. \& Re, D. (2008). Elevated pretreatment interleukin-10 serum level is an International Prognostic Score (IPS)-independent risk factor for early treatment failure in advanced stage Hodgkin lymphoma. Leuk Lymphoma, Vol.49, No.11, pp. 2091-2098, 1029-2403

Rehwald, U.; Schulz, H.; Reiser, M.; Sieber, M.; Staak, J.O.; Morschlauser, F.; Driessen, C.; Rudiger, T.; Muller-Hermelin, K.; Diehl, V.; Engert, A. (2003). Treatment of relapsed $\mathrm{CD} 20+$ Hodgkin lymphoma with the monoclonal antibody rituximab is 
effective and well tolerated: results of a phase 2 trial of the German Hodgkin lymphoma study group. Blood, Vol 101, No 2, pp 420-424, 0006-4971

Ren, F.; Zhan, X.; Martens, G.; Lee, J.; Center, D.; Hanson, S.K. \& Kornfeld, H. (2005). Pro-IL16 regulation in activated murine CD4+ lymphocytes. J Immunol, Vol.174, No.5, pp. 2738-2745, 0022-1767

Renne, C.; Martin-Subero, J.I.; Eickernjager, M.; Hansmann, M.L.; Kuppers, R.; Siebert, R. \& Brauninger, A. (2006). Aberrant expression of ID2, a suppressor of B-cell-specific gene expression, in Hodgkin's lymphoma. Am J Pathol, Vol.169, No.2, pp. 655-664, 0002-9440

Rickinson, A. \& Kieff, E. (2001). Epstein-Barr virus. In: In Fields Virology, Knipe DM H.P.e. (eds),2575-2627. Lippincott Williams \& Wilkins Philadelphia

Rohr, J.C.; Wagner, H.J.; Lauten, M.; Wacker, H.H.; Juttner, E.; Hanke, C.; Pohl, M. \& Niemeyer, C.M. (2008). Differentiation of EBV-induced post-transplant Hodgkin lymphoma from Hodgkin-like post-transplant lymphoproliferative disease. Pediatr Transplant, Vol.12, No.4, pp. 426-431, 1399-3046

Roskrow, M.A.; Suzuki, N.; Gan, Y.; Sixbey, J.W.; Ng, C.Y.; Kimbrough, S.; Hudson, M.; Brenner, M.K.; Heslop, H.E. \& Rooney, C.M. (1998). Epstein-Barr virus (EBV)specific cytotoxic T lymphocytes for the treatment of patients with EBV-positive relapsed Hodgkin's disease. Blood, Vol.91, No.8, pp. 2925-2934, 0006-4971

Rudant, J.; Orsi, L.; Monnereau, A.; Patte, C.; Pacquement, H.; Landman-Parker, J.; Bergeron, C.; Robert, A.; Michel, G.; Lambilliotte, A.; Aladjidi, N.; Gandemer, V.; Lutz, P.; Margueritte, G.; Plantaz, D.; Mechinaud, F.; Hemon, D. \& Clavel, J. (2010). Childhood hodgkin's lymphoma, non-Hodgkin's lymphoma and factors related to the immune system: the Escale study (SFCE). Int J Cancer, pp. 1097-0215, 0020-7136

Sabattini, E.; Gerdes, J.; Gherlinzoni, F.; Poggi, S.; Zucchini, L.; Melilli, G.; Grigioni, F.; Del Vecchio, M.T.; Leoncini, L. \& Falini, B. (1993). Comparison between the monoclonal antibodies Ki-67 and PC10 in 125 malignant lymphomas. J Pathol, Vol.169, No.4, pp. 397-403, 0022-3417

Sanchez-Aguilera, A.; Montalban, C.; de la Cueva, P.; Sanchez-Verde, L.; Morente, M.M.; Garcia-Cosio, M.; Garcia-Larana, J.; Bellas, C.; Provencio, M.; Romagosa, V.; de Sevilla, A.F.; Menarguez, J.; Sabin, P.; Mestre, M.J.; Mendez, M.; Fresno, M.F.; Nicolas, C.; Piris, M.A. \& Garcia, J.F. (2006). Tumor microenvironment and mitotic checkpoint are key factors in the outcome of classic Hodgkin lymphoma. Blood, Vol.108, No.2, pp. 662-668, 0006-4971

Sanchez-Beato, M.; Piris, M.A.; Martinez-Montero, J.C.; Garcia, J.F.; Villuendas, R.; Garcia, F.J.; Orradre, J.L. \& Martinez, P. (1996). MDM2 and p21WAF1/CIP1, wild-type p53-induced proteins, are regularly expressed by Sternberg-Reed cells in Hodgkin's disease. J Pathol, Vol.180, No.1, pp. 58-64, 0022-3417

Sanchez-Beato, M.; Sanchez-Aguilera, A. \& Piris, M.A. (2003). Cell cycle deregulation in Bcell lymphomas. Blood, Vol.101, No.4, pp. 1220-1235, 0006-4971

Sarris, A.H.; Kliche, K.O.; Pethambaram, P.; Preti, A.; Tucker, S.; Jackow, C.; Messina, O.; Pugh, W.; Hagemeister, F.B.; McLaughlin, P.; Rodriguez, M.A.; Romaguera, J.; Fritsche, H.; Witzig, T.; Duvic, M.; Andreeff, M. \& Cabanillas, F. (1999). Interleukin10 levels are often elevated in serum of adults with Hodgkin's disease and are associated with inferior failure-free survival. Ann Oncol, Vol.10, No.4, pp. 433-440, 0923-7534 
Schmitz, R.; Hansmann, M.L.; Bohle, V.; Martin-Subero, J.I.; Hartmann, S.; Mechtersheimer, G.; Klapper, W.; Vater, I.; Giefing, M.; Gesk, S.; Stanelle, J.; Siebert, R. \& Kuppers, R. (2009). TNFAIP3 (A20) is a tumor suppressor gene in Hodgkin lymphoma and primary mediastinal B cell lymphoma. J Exp Med, Vol.206, No.5, pp. 981-989, 15409538

Schnell, R.; Dietlein, M.; Staak, J.O.; Borchmann, P.; Schomaecker, K.; Fischer, T.; Eschner, W.; Hansen, H.; Morschhauser, F.; Schicha, H.; Diehl, V.; Raubitschek, A. \& Engert, A. (2005). Treatment of refractory Hodgkin's lymphoma patients with an iodine131-labeled murine anti-CD30 monoclonal antibody. J Clin Oncol, Vol.23, No.21, pp. 4669-4678, 0732-183X

Schulz, H.; Rehwald, U.; Morschhauser, F.; Elter, T.; Driessen, C.; Rudiger, T.; Borchmann, P.; Schnell, R.; Diehl, V.; Engert, A. \& Reiser, M. (2008). Rituximab in relapsed lymphocyte-predominant Hodgkin lymphoma: long-term results of a phase 2 trial by the German Hodgkin Lymphoma Study Group (GHSG). Blood, Vol.111, No.1, pp. 109-111, 0006-4971

Schwering, I.; Brauninger, A.; Klein, U.; Jungnickel, B.; Tinguely, M.; Diehl, V.; Hansmann, M.L.; Dalla-Favera, R.; Rajewsky, K. \& Kuppers, R. (2003). Loss of the B-lineagespecific gene expression program in Hodgkin and Reed-Sternberg cells of Hodgkin lymphoma. Blood, Vol.101, No.4, pp. 1505-1512, 0006-4971

Seitz, V.; Hummel, M.; Marafioti, T.; Anagnostopoulos, I.; Assaf, C. \& Stein, H. (2000). Detection of clonal T-cell receptor gamma-chain gene rearrangements in ReedSternberg cells of classic Hodgkin disease. Blood, Vol.95, No.10, pp. 3020-3024, 00064971

Shaffer, A.L.; Yu, X.; He, Y.; Boldrick, J.; Chan, E.P. \& Staudt, L.M. (2000). BCL-6 represses genes that function in lymphocyte differentiation, inflammation, and cell cycle control. Immunity, Vol.13, No.2, pp. 199-212, 1074-7613

Shimizu, J.; Yamazaki, S.; Takahashi, T.; Ishida, Y. \& Sakaguchi, S. (2002). Stimulation of CD25(+)CD4(+) regulatory $\mathrm{T}$ cells through GITR breaks immunological selftolerance. Nat Immunol, Vol.3, No.2, pp. 135-142, 1529-2908

Skinnider, B.F.; Elia, A.J.; Gascoyne, R.D.; Patterson, B.; Trumper, L.; Kapp, U. \& Mak, T.W. (2002). Signal transducer and activator of transcription 6 is frequently activated in Hodgkin and Reed-Sternberg cells of Hodgkin lymphoma. Blood, Vol.99, No.2, pp. 618-626, 0006-4971

Skinnider, B.F. \& Mak, T.W. (2002). The role of cytokines in classical Hodgkin lymphoma. Blood, Vol.99, No.12, pp. 4283-4297, 0006-4971

Slovak, M.L.; Bedell, V.; Hsu, Y.H.; Estrine, D.B.; Nowak, N.J.; Delioukina, M.L.; Weiss, L.M.; Smith, D.D. \& Forman, S.J. (2011). Molecular karyotypes of Hodgkin and ReedSternberg cells at disease onset reveal distinct copy number alterations in chemosensitive versus refractory Hodgkin lymphoma. Clin Cancer Res, Vol.17, No.10, pp. 3443-3454, 1078-0432

Smith, E.M.; Akerblad, P.; Kadesch, T.; Axelson, H. \& Sigvardsson, M. (2005). Inhibition of EBF function by active Notch signaling reveals a novel regulatory pathway in early B-cell development. Blood, Vol.106, No.6, pp. 1995-2001, 0006-4971

Smolewski, P.; Robak, T.; Krykowski, E.; Blasinska-Morawiec, M.; Niewiadomska, H.; Pluzanska, A.; Chmielowska, E. \& Zambrano, O. (2000). Prognostic factors in 
Hodgkin's disease: multivariate analysis of 327 patients from a single institution. Clin Cancer Res, Vol.6, No.3, pp. 1150-1160, 1078-0432

Smyth, M.J.; Hayakawa, Y.; Takeda, K. \& Yagita, H. (2002). New aspects of natural-killer-cell surveillance and therapy of cancer. Nat Rev Cancer, Vol.2, No.11, pp. 850-861, 1474$175 X$

Song, L.; Li, Y.; Sun, Y. \& Shen, B. (2002). Mcl-1 mediates cytokine deprivation induced apoptosis of human myeloma cell line XG-7. Chin Med J (Engl), Vol.115, No.8, pp. 1241-1243, 0366-6999

Specht, L. \& Hasenclever, D. (1999). Prognostic factors of Hodgkin's disease. In: Hodgkin's disease. , Mauch PM A.J., Diehl V, Hoppe RT, Weiss LM (eds). (eds),295-325. Lippincott Williams \& Wilkins Philadelphia:295-325

Staudt, L.M. (2000). The molecular and cellular origins of Hodgkin's disease. J Exp Med, Vol.191, No.2, pp. 207-212, 0022-1007

Steidl, C.; Connors, J.M. \& Gascoyne, R.D. (2011a). Molecular pathogenesis of Hodgkin's lymphoma: increasing evidence of the importance of the microenvironment. J Clin Oncol, Vol.29, No.14, pp. 1812-1826, 1527-7755

Steidl, C.; Lee, T.; Shah, S.P.; Farinha, P.; Han, G.; Nayar, T.; Delaney, A.; Jones, S.J.; Iqbal, J.; Weisenburger, D.D.; Bast, M.A.; Rosenwald, A.; Muller-Hermelink, H.K.; Rimsza, L.M.; Campo, E.; Delabie, J.; Braziel, R.M.; Cook, J.R.; Tubbs, R.R.; Jaffe, E.S.; Lenz, G.; Connors, J.M.; Staudt, L.M.; Chan, W.C. \& Gascoyne, R.D. (2010). Tumorassociated macrophages and survival in classic Hodgkin's lymphoma. $N$ Engl J Med, Vol.362, No.10, pp. 875-885, 1533-4406

Steidl, C.; Shah, S.P.; Woolcock, B.W.; Rui, L.; Kawahara, M.; Farinha, P.; Johnson, N.A.; Zhao, Y.; Telenius, A.; Neriah, S.B.; McPherson, A.; Meissner, B.; Okoye, U.C.; Diepstra, A.; van den Berg, A.; Sun, M.; Leung, G.; Jones, S.J.; Connors, J.M.; Huntsman, D.G.; Savage, K.J.; Rimsza, L.M.; Horsman, D.E.; Staudt, L.M.; Steidl, U.; Marra, M.A. \& Gascoyne, R.D. (2011b). MHC class II transactivator CIITA is a recurrent gene fusion partner in lymphoid cancers. Nature, Vol.471, No.7338, pp. 377-381, 1476-4687

Stein, H.; Delsol, G. \& Pileri, S. (2008a). Classical Hodgkin lymphoma, introduction. In: WHO Classification of Tumours of Haematopoietic and Lymphoid Tissues. , Swerdlow SH C.E., Harris NL, et al. (eds) (eds),326-329. IARC Lyon

Stein, H.; Marafioti, T.; Foss, H.D.; Laumen, H.; Hummel, M.; Anagnostopoulos, I.; Wirth, T.; Demel, G. \& Falini, B. (2001). Down-regulation of BOB.1/OBF.1 and Oct2 in classical Hodgkin disease but not in lymphocyte predominant Hodgkin disease correlates with immunoglobulin transcription. Blood, Vol.97, No.2, pp. 496-501, 0006-4971

Stein, R.; Von Wasielewski; Poppema, S.; MacLennan, K. \& Guenova, M. (2008b). Nodular sclerosis classical Hodgkin lymphoma. In: WHO Classification of Tumors of Haematopoietic and Lymphoid Tissues Swerdlow S., Campo E., Harris N., Jaffe E., Pileri S., Stein H., al. e. (eds),330, IARC, Lyon, France

Stupp, R. \& Ruegg, C. (2007). Integrin inhibitors reaching the clinic. J Clin Oncol, Vol.25, No.13, pp. 1637-1638, 1527-7755

Sup, S.J.; Alemany, C.A.; Pohlman, B.; Elson, P.; Malhi, S.; Thakkar, S.; Steinle, R. \& Hsi, E.D. (2005). Expression of bcl-2 in classical Hodgkin's lymphoma: an independent predictor of poor outcome. J Clin Oncol, Vol.23, No.16, pp. 3773-3779, 0732-183X 
Suri-Payer, E.; Amar, A.Z.; Thornton, A.M. \& Shevach, E.M. (1998). CD4+CD25+ T cells inhibit both the induction and effector function of autoreactive $\mathrm{T}$ cells and represent a unique lineage of immunoregulatory cells. J Immunol, Vol.160, No.3, pp. 1212-1218,

Sutmuller, R.P.; van Duivenvoorde, L.M.; van Elsas, A.; Schumacher, T.N.; Wildenberg, M.E.; Allison, J.P.; Toes, R.E.; Offringa, R. \& Melief, C.J. (2001). Synergism of cytotoxic T lymphocyte-associated antigen 4 blockade and depletion of CD25(+) regulatory $\mathrm{T}$ cells in antitumor therapy reveals alternative pathways for suppression of autoreactive cytotoxic T lymphocyte responses. J Exp Med, Vol.194, No.6, pp. 823-832

Swerdlow, S.; Campo, E. \& Harris, N. (2008a). Pathology and Genetics of Tumours of Haematopoietic and Lymphoid Tissues. In: World Health Organization Classification of Tumours, Swerdlow SH C.E., Harris NL (eds). IARC Press Lyon

Swerdlow, S.; Campo, E.; Harris. NL; Jaffe, E.; Pileri, S.; Stein, H.; Thiele, J. \& Vardiman, J. (2008b). WHO classification of tumours of haematopoietic and lymphoid tissues. IARC Press Lyon, France

Swerdlow, S.; Webber, S.; A., C. \& Ferry, J. (2008c). Post-transplant lymphoproliferative disorders. In: World Health Organization Classification of Tumours, Pathology and Genetics of Tumours of Haematopoietic and Lymphoid Tissues. , Swerdlow SH C.E., Harris NL, et al. (eds) (eds),343-349. IARC Press Lyon

Takahashi, T.; Tagami, T.; Yamazaki, S.; Uede, T.; Shimizu, J.; Sakaguchi, N.; Mak, T.W. \& Sakaguchi, S. (2000). Immunologic self-tolerance maintained by CD25(+)CD4(+) regulatory $\mathrm{T}$ cells constitutively expressing cytotoxic $\mathrm{T}$ lymphocyte-associated antigen 4. J Exp Med, Vol.192, No.2, pp. 303-310, 0022-1007

Tang, T.T.; Dowbenko, D.; Jackson, A.; Toney, L.; Lewin, D.A.; Dent, A.L. \& Lasky, L.A. (2002). The forkhead transcription factor AFX activates apoptosis by induction of the BCL-6 transcriptional repressor. J Biol Chem, Vol.277, No.16, pp. 14255-14265, 0021-9258

Tazzari, P.L.; Bolognesi, A.; de Totero, D.; Falini, B.; Lemoli, R.M.; Soria, M.R.; Pileri, S.; Gobbi, M.; Stein, H.; Flenghi, L. \& et al. (1992). Ber-H2 (anti-CD30)-saporin immunotoxin: a new tool for the treatment of Hodgkin's disease and CD30+ lymphoma: in vitro evaluation. Br J Haematol, Vol.81, No.2, pp. 203-211, 0007-1048

Tedoldi, S.; Mottok, A.; Ying, J.; Paterson, J.C.; Cui, Y.; Facchetti, F.; van Krieken, J.H.; Ponzoni, M.; Ozkal, S.; Masir, N.; Natkunam, Y.; Pileri, S.; Hansmann, M.L.; Mason, D.; Tao, Q. \& Marafioti, T. (2007). Selective loss of B-cell phenotype in lymphocyte predominant Hodgkin lymphoma. J Pathol, Vol.213, No.4, pp. 429-440, 0022-3417

Teichmann, M.; Meyer, B.; Beck, A. \& Niedobitek, G. (2005). Expression of the interferoninducible chemokine IP-10 (CXCL10), a chemokine with proposed anti-neoplastic functions, in Hodgkin lymphoma and nasopharyngeal carcinoma. J Pathol, Vol.206, No.1, pp. 68-75, 0022-3417

ten Berge, R.L.; Oudejans, J.J.; Dukers, D.F.; Meijer, J.W.; Ossenkoppele, G.J. \& Meijer, C.J. (2001). Percentage of activated cytotoxic T-lymphocytes in anaplastic large cell lymphoma and Hodgkin's disease: an independent biological prognostic marker. Leukemia, Vol.15, No.3, pp. 458-464 
Teramoto, N.; Pokrovskaja, K.; Szekely, L.; Polack, A.; Yoshino, T.; Akagi, T. \& Klein, G. (1999). Expression of cyclin D2 and D3 in lymphoid lesions. Int J Cancer, Vol.81, No.4, pp. 543-550, 0020-7136

Tesniere, A.; Apetoh, L.; Ghiringhelli, F.; Joza, N.; Panaretakis, T.; Kepp, O.; Schlemmer, F.; Zitvogel, L. \& Kroemer, G. (2008). Immunogenic cancer cell death: a key-lock paradigm. Curr Opin Immunol, Vol.20, No.5, pp. 504-511, 0952-7915

Thomas, R.K.; Re, D.; Wolf, J. \& Diehl, V. (2004). Part I: Hodgkin's lymphoma--molecular biology of Hodgkin and Reed-Sternberg cells. Lancet Oncol, Vol.5, No.1, pp. 11-18, 1470-2045

Thome, M. \& Tschopp, J. (2001). Regulation of lymphocyte proliferation and death by FLIP. Nat Rev Immunol, Vol.1, No.1, pp. 50-58, 1474-1733

Tirelli, U.; Errante, D.; Dolcetti, R.; Gloghini, A.; Serraino, D.; Vaccher, E.; Franceschi, S.; Boiocchi, M. \& Carbone, A. (1995). Hodgkin's disease and human immunodeficiency virus infection: clinicopathologic and virologic features of 114 patients from the Italian Cooperative Group on AIDS and Tumors. J Clin Oncol, Vol.13, No.7, pp. 1758-1767, 0732-183X

Tlsty, T.D. \& Coussens, L.M. (2006). Tumor stroma and regulation of cancer development. Annu Rev Pathol, Vol.1, pp. 119-150, 1553-4006

Tsavaris, N.; Kosmas, C.; Vadiaka, M.; Kanelopoulos, P. \& Boulamatsis, D. (2002). Immune changes in patients with advanced breast cancer undergoing chemotherapy with taxanes. Br J Cancer, Vol.87, No.1, pp. 21-27, 0007-0920

Tzankov, A.; Krugmann, J.; Fend, F.; Fischhofer, M.; Greil, R. \& Dirnhofer, S. (2003a). Prognostic significance of CD20 expression in classical Hodgkin lymphoma: a clinicopathological study of 119 cases. Clin Cancer Res, Vol.9, No.4, pp. 1381-1386, 1078-0432

Tzankov, A.; Zimpfer, A.; Lugli, A.; Krugmann, J.; Went, P.; Schraml, P.; Maurer, R.; Ascani, S.; Pileri, S.; Geley, S. \& Dirnhofer, S. (2003b). High-throughput tissue microarray analysis of G1-cyclin alterations in classical Hodgkin's lymphoma indicates overexpression of cyclin E1. J Pathol, Vol.199, No.2, pp. 201-207

Tzankov, A.; Zimpfer, A.; Pehrs, A.C.; Lugli, A.; Went, P.; Maurer, R.; Pileri, S. \& Dirnhofer, S. (2003c). Expression of B-cell markers in classical hodgkin lymphoma: a tissue microarray analysis of 330 cases. Mod Pathol, Vol.16, No.11, pp. 1141-1147, 08933952

Tzardi, M.; Kouvidou, C.; Panayiotides, I.; Koutsoubi, K.; Stefanaki, K.; Giannikaki, E.; Darivianaki, K.; Zois, M.; Eliopoulos, G.; Kakolyris, S.; Delides, G.; Rontogianni, D. \& Kanavaros, P. (1996). Expression of p53 and mdm-2 proteins in Hodgkin's Disease. Absence of correlation with the presence of Epstein-Barr virus. Anticancer Res, Vol.16, No.5A, pp. 2813-2819, 0250-7005

Ushmorov, A.; Leithauser, F.; Sakk, O.; Weinhausel, A.; Popov, S.W.; Moller, P. \& Wirth, T. (2006). Epigenetic processes play a major role in B-cell-specific gene silencing in classical Hodgkin lymphoma. Blood, Vol.107, No.6, pp. 2493-2500, 0006-4971

Ushmorov, A.; Ritz, O.; Hummel, M.; Leithauser, F.; Moller, P.; Stein, H. \& Wirth, T. (2004). Epigenetic silencing of the immunoglobulin heavy-chain gene in classical Hodgkin lymphoma-derived cell lines contributes to the loss of immunoglobulin expression. Blood, Vol.104, No.10, pp. 3326-3334, 0006-4971 
Vaccher, E.; Spina, M.; Talamini, R.; Zanetti, M.; di Gennaro, G.; Nasti, G.; Tavio, M.; Bernardi, D.; Simonelli, C. \& Tirelli, U. (2003). Improvement of systemic human immunodeficiency virus-related non-Hodgkin lymphoma outcome in the era of highly active antiretroviral therapy. Clin Infect Dis, Vol.37, No.11, pp. 1556-1564, 1537-6591

van den Berg, A.; Visser, L. \& Poppema, S. (1999). High expression of the CC chemokine TARC in Reed-Sternberg cells. A possible explanation for the characteristic T-cell infiltratein Hodgkin's lymphoma. Am J Pathol, Vol.154, No.6, pp. 1685-1691, 00029440

Vassilakopoulos, T.P.; Nadali, G.; Angelopoulou, M.K.; Siakantaris, M.P.; Dimopoulou, M.N.; Kontopidou, F.N.; Rassidakis, G.Z.; Doussis-Anagnostopoulou, I.A.; Hatzioannou, M.; Vaiopoulos, G.; Kittas, C.; Sarris, A.H.; Pizzolo, G. \& Pangalis, G.A. (2001). Serum interleukin-10 levels are an independent prognostic factor for patients with Hodgkin's lymphoma. Haematologica, Vol.86, No.3, pp. 274-281, 03906078

Viviani, S.; Notti, P.; Bonfante, V.; Verderio, P.; Valagussa, P. \& Bonadonna, G. (2000). Elevated pretreatment serum levels of Il-10 are associated with a poor prognosis in Hodgkin's disease, the milan cancer institute experience. Med Oncol, Vol.17, No.1, pp. 59-63, 1357-0560

Wagner, E.F.; Hleb, M.; Hanna, N. \& Sharma, S. (1998). A pivotal role of cyclin D3 and cyclin-dependent kinase inhibitor p27 in the regulation of IL-2-, IL-4-, or IL-10mediated human B cell proliferation. J Immunol, Vol.161, No.3, pp. 1123-1131, 00221767

Watanabe, K.; Yamashita, Y.; Nakayama, A.; Hasegawa, Y.; Kojima, H.; Nagasawa, T. \& Mori, N. (2000). Varied B-cell immunophenotypes of Hodgkin/Reed-Sternberg cells in classic Hodgkin's disease. Histopathology, Vol.36, No.4, pp. 353-361, 03090167

Wei, W.Z.; Morris, G.P. \& Kong, Y.C. (2004). Anti-tumor immunity and autoimmunity: a balancing act of regulatory T cells. Cancer Immunol Immunother, Vol.53, No.2, pp. 7378

Weihrauch, M.R.; Manzke, O.; Beyer, M.; Haverkamp, H.; Diehl, V.; Bohlen, H.; Wolf, J. \& Schultze, J.L. (2005). Elevated serum levels of CC thymus and activation-related chemokine (TARC) in primary Hodgkin's disease: potential for a prognostic factor. Cancer Res, Vol.65, No.13, pp. 5516-5519, 0008-5472

Weniger, M.A.; Melzner, I.; Menz, C.K.; Wegener, S.; Bucur, A.J.; Dorsch, K.; Mattfeldt, T.; Barth, T.F. \& Moller, P. (2006). Mutations of the tumor suppressor gene SOCS-1 in classical Hodgkin lymphoma are frequent and associated with nuclear phosphoSTAT5 accumulation. Oncogene, Vol.25, No.18, pp. 2679-2684, 0950-9232

Willenbrock, K.; Roers, A.; Blohbaum, B.; Rajewsky, K. \& Hansmann, M.L. (2000). CD8(+) T cells in Hodgkin's disease tumor tissue are a polyclonal population with limited clonal expansion but little evidence of selection by antigen. Am J Pathol, Vol.157, No.1, pp. 171-175

Wolf, A.M.; Wolf, D.; Steurer, M.; Gastl, G.; Gunsilius, E. \& Grubeck-Loebenstein, B. (2003). Increase of regulatory $\mathrm{T}$ cells in the peripheral blood of cancer patients. Clin Cancer Res, Vol.9, No.2, pp. 606-612, 1078-0432 
Wood, K.M.; Roff, M. \& Hay, R.T. (1998). Defective IkappaBalpha in Hodgkin cell lines with constitutively active NF-kappaB. Oncogene, Vol.16, No.16, pp. 2131-2139, 0950-9232

Xicoy, B.; Ribera, J.M.; Miralles, P.; Berenguer, J.; Rubio, R.; Mahillo, B.; Valencia, M.E.; Abella, E.; Lopez-Guillermo, A.; Sureda, A.; Morgades, M.; Navarro, J.T. \& Esteban, H. (2007). Results of treatment with doxorubicin, bleomycin, vinblastine and dacarbazine and highly active antiretroviral therapy in advanced stage, human immunodeficiency virus-related Hodgkin's lymphoma. Haematologica, Vol.92, No.2, pp. 191-198, 1592-8721

Yamamoto, R.; Nishikori, M.; Kitawaki, T.; Sakai, T.; Hishizawa, M.; Tashima, M.; Kondo, T.; Ohmori, K.; Kurata, M.; Hayashi, T. \& Uchiyama, T. (2008). PD-1-PD-1 ligand interaction contributes to immunosuppressive microenvironment of Hodgkin lymphoma. Blood, Vol.111, No.6, pp. 3220-3224, 0006-4971

Younes, A. (2009). Novel treatment strategies for patients with relapsed classical Hodgkin lymphoma. Hematology Am Soc Hematol Educ Program, pp. 507-519, 1520-4383

Younes, A.; Bartlett, N.L.; Leonard, J.P.; Kennedy, D.A.; Lynch, C.M.; Sievers, E.L. \& ForeroTorres, A. (2010). Brentuximab vedotin (SGN-35) for relapsed CD30-positive lymphomas. N Engl J Med, Vol.363, No.19, pp. 1812-1821, 1533-4406

Young, L.S. \& Rickinson, A.B. (2004). Epstein-Barr virus: 40 years on. Nat Rev Cancer, Vol.4, No.10, pp. 757-768, 1474-175X

Zheng, B.; Fiumara, P.; Li, Y.V.; Georgakis, G.; Snell, V.; Younes, M.; Vauthey, J.N.; Carbone, A. \& Younes, A. (2003). MEK/ERK pathway is aberrantly active in Hodgkin disease: a signaling pathway shared by CD30, CD40, and RANK that regulates cell proliferation and survival. Blood, Vol.102, No.3, pp. 1019-1027, 0006-4971

Zhu, J. \& Paul, W.E. (2008). CD4 T cells: fates, functions, and faults. Blood, Vol.112, No.5, pp. $1557-1569,1528-0020$ 


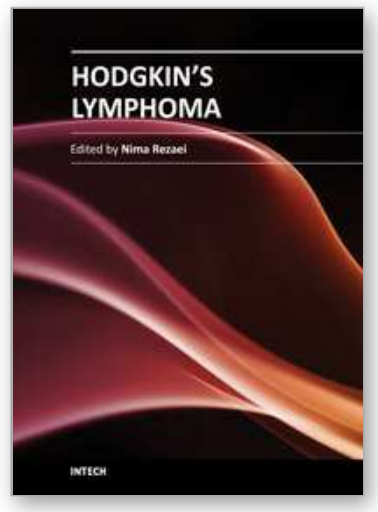

\author{
Hodgkin's Lymphoma \\ Edited by Dr. Nima Rezaei
}

ISBN 978-953-51-0402-5

Hard cover, 272 pages

Publisher InTech

Published online 23, March, 2012

Published in print edition March, 2012

Hodgkin's Lymphoma is the book consisting of 11 chapters: Recent insights into the biology of Hodgkin's lymphoma, including historical aspects, epidemiology, pathophysiology, genetic defects, and prognostic indicators are explained in the intro chapters. After a translational chapter from tumor microenvironment to immunotherapeutic approach, treatment of early stage, advanced, and refractory Hodgkin's lymphoma are explained in the following chapters. MALT lymphoma and adverse effects of chemotherapy and radiotherapy in the affected patients are discussed in the subsequent chapters, while the final chapter is focused on survivorship in Hodgkin's lymphoma. The book is intended to present recent advances in the pathophysiology of Hodgkin's lymphoma as well as practical approach to diagnosis and management in clinical practice, which is hoped to be welcomed by the physicians, who wish to learn more about Hodgkin's lymphoma.

\title{
How to reference
}

In order to correctly reference this scholarly work, feel free to copy and paste the following:

Marylène Lejeune, Luis de la Cruz-Merino and Tomás Álvaro (2012). Hodgkin's Lymphoma: From Tumor Microenvironment to Immunotherapeutic Approach - Body's Own Power Protection Challenges, Hodgkin's Lymphoma, Dr. Nima Rezaei (Ed.), ISBN: 978-953-51-0402-5, InTech, Available from:

http://www.intechopen.com/books/hodgkin-s-lymphoma/hodgkin-s-lymphoma-from-tumor-microenvironmentto-immunotherapeutic-approach-body-s-own-power-protec

\section{INTECH}

open science | open minds

\section{InTech Europe}

University Campus STeP Ri

Slavka Krautzeka 83/A

51000 Rijeka, Croatia

Phone: +385 (51) 770447

Fax: +385 (51) 686166

www.intechopen.com

\section{InTech China}

Unit 405, Office Block, Hotel Equatorial Shanghai

No.65, Yan An Road (West), Shanghai, 200040, China 中国上海市延安西路65号上海国际贵都大饭店办公楼 405 单元

Phone: +86-21-62489820

Fax: $+86-21-62489821$ 
(C) 2012 The Author(s). Licensee IntechOpen. This is an open access article distributed under the terms of the Creative Commons Attribution 3.0 License, which permits unrestricted use, distribution, and reproduction in any medium, provided the original work is properly cited. 